Bangl. J. Vet. Med. (2011). 9 (2): 95 - 120

\title{
PUBLIC HEALTH THREAT CAUSED BY ZOONOTIC DISEASES IN BANGLADESH
}

\author{
M. A. Samad \\ Department of Medicine, Faculty of Veterinary Science, Bangladesh agricultural University \\ Mymensingh-2202, Bangladesh
}

\begin{abstract}
Diseases and infections shared between animals and humans are mainly called zoonotic diseases which may be categorized as emerging, reemerging and neglected. All types of these diseases occur throughout the world including Bangladesh. The results on the prevalence and effects of zoonotic diseases in humans and animals of Bangladesh are analyzed from the published literatures and presented in this report. It appears from the literature that there are about 1415 human pathogens of which $61 \%$ are zoonotic and nearly half of all human pathogens can be classified as emerging, of which $75 \%$ of these are caused by zoonotic pathogens. The major zoonotic bacterial diseases recorded in Bangladesh are Anthrax, Tuberculosis, Brucellosis, Salmonellosis, Campylobacteriosis and Leptospirosis, of which only Anthrax has been reported as clinical outbreaks form in both the humans and cattle. During the period 2009 to 2012, anthrax caused death of hundreds of cattle and more than 650 cases of cutaneous anthrax in humans including fatalities in two humans associated with anthrax. The major reported viral zoonotic diseases in Bangladesh include Avian influenza, Rabies, Nipah virus infection, Japanese encephalitis, Rotavirus and Dengue fever. Avian influenza caused by highly pathogenic H5N1 in humans and poultry in Bangladesh and about six humans affected with H5N1 but all of them have recovered. Since 27 March 2007 when Avian influenza was reported to have occurred for the first time in Bangladesh, this virus spread in 51 out of 64 districts with more than 480 outbreaks, culled more than two million poultry birds and cost Tk. 55 billion (US \$ 757.9 million) in Bangladesh. Rabies is considered as a priority zoonosis in Bangladesh and it is mainly transmitted to humans and food animals mainly through dog bite nearly 100,000 people and at least 2000 died of rabies in 2009 in Bangladesh. Nipah virus infection is an important emerging infectious disease has been recognized since 2001 in Bangladesh and up to February 2011, 173 humans cases have been identified, of which $110(63.58 \%)$ died. Japanese encephalitis (JE) is a vector borne zoonotic disease, first recognized in Bangladesh since an outbreak in 1977 and $12.38 \%$ encephalitis patients had JE virus infection which was associated with mortality, physical disability and cognitive difficulties. Rotavirus is a worldwide distributed zoonotic disease affecting mammals and birds and it has been reported from Bangladesh in humans (23.75\%), animals (12 to 43.78\%) and broiler birds $(13.15 \%)$ associated with diarrheic syndrome. Dengue fever was first reported in Bangladesh in 1964 and outbreak that began in 2000 predominantly caused by DENV-3 in which 5551 cases recovered and 93 Dengue related deaths were reported. The dermatomycosis has been reported in $9.3 \%$ cattle, $18.6 \%$ goats and $25.2 \%$ in contact humans. The major zoonotic parasites recorded in cats in Bangladesh include Paragonimus westermani (9.09\%), Ancyclostoma tubaeforme (36.36\%), Dirofilaria immitis (9.09\%), Toxocara cati (45.45\%) and Toxoplasma gondii (9.09\%), in dogs include Diphyllobothrium latum (13.3\%), Diphylidium caninum (16.69\%), Echinococcus granulosus (9.17\%), Ancylostomum caninum (9-100\%), Gnathostoma spingerum (40.0\%), Toxocara canis (23.3\%), Trichuris vulpis $(13.8 \%)$ and in pigs include Entaemebea histolytica (17.24\%) and Balantidium coli $(60.34 \%)$. The prevalence of zoonotic protozoan diseases recorded in humans in Bangladesh include amebiasis (E. histolytica $4.71 \%$ \& E. dispar $12.6 \%)$, giardiasis $(21 \%$ in children \& $51 \%$ in malnourished children), cryptosporidiasis (1.4 to $3.5 \%$ in diarrheic patients) and visceral leishmaniasis (kala-azar) which was first reported in Jassore in 1824 but still sporadic outbreaks are occurring in the different districts in Bangladesh. Sero-surveillance studies showed 16 to $17 \%$ cattle, 17.65 to $53.6 \%$ sheep, 12.09 to $35.4 \%$ goats and $15.89 \%$ women had $T$. gondii antibodies in Bangladesh. It appears from these results that all types of emerging, reemerging and neglected zoonotic diseases are widely prevalent and pose a great threat to human health in Bangladesh. Neglected Veterinary medical profession and its extension services, poor people without any knowledge of zoonotic diseases who are in close contact with livestock and their products, and unhygienic processing, maintaining and marketing the livestock and livestock products have made the situation graver in Bangladesh.
\end{abstract}

Key words: Zoonotic diseases, bacterial, viral, parasitic, fungal, humans, animals, birds, Bangladesh

\section{INTRODUCTION}

WHO defines zoonoses as 'those diseases and infections which are naturally transmitted between vertebrate animals and man.' There are approximately 1415 pathogens known to affect humans, of which about $61 \%$ of all human pathogens are zoonotic (Anon, 2011d). Nearly half of all humans' infectious diseases known today can be classified as emerging and about $75 \%$ of emerging infectious diseases are caused by zoonotic pathogens.

*Corresponding e-mail address: vetmedbd@yahoo.com

Copyright ( 2011 Bangladesh Society for Veterinary Medicine

All right reserved 1729-7893/0228/2011 


\section{A. Samad}

Emerging diseases that (a) have been recently recognized or evolved, (b) have recently increased in incidence or prevalence, (c) have recently expanded in geographic or climatologic range or (d) have transpired from animal populations into humans. This differs somewhat from reemerging infectious diseases, which are diseases that have been discovered previously in a species often at enzootic levels but for some reason, have significantly increased in incidence at a given point of time or in a specific geographic region (Anon., 2011e). Zoonotic diseases have both direct and indirect effects on livestock health and production. The direct impact of zoonoses can be considerable with illness, monetary loss, adverse effect on morale of personnel, unfavorable publicity and legal implications. Indirect effects occur as a result of the risk of human infection, barriers to livestock trade, the added costs associated with control programs, marketing produce to ensure it is safe for human consumption and the loss of market awing to reduce consumer confidence (Anon., 2011e,f). A recent retrospective study of 335 emerging infections episodes over a 64-year period (1940-2004) emphasized the role of wildlife as a source of emerging infections, although research efforts have so far been focused toward either humans or economically related species (Daszak et al., 2007). Zoonotic diseases are common throughout the world and the public health threat of emerging, reemerging and neglected zoonoses in the industrial world has been reported (Cutler et al., 2010; Weese et al., 2002) but it constitutes an important threat to human health in developing countries like Bangladesh. An overview of livestock research reports published during the twentieth century in Bangladesh has been reviewed (Samad, 2000b). This paper describes the summarized results of the available published inland research reports on the prevalence and effects of zoonotic diseases in humans and animals, which could be helpful for planning to prevent these communicable diseases in endemic population in Bangladesh.

\section{Major bacterial zoonotic diseases \\ Anthrax}

The word anthrax is derived from the Greek word, 'anthrakis' (or 'coal') in reference to the black skin lesions victims develop. The disease occurs worldwide and is enzootic in certain African and Asian countries including Bangladesh. It is caused by Bacillus anthracis which are mainly released from infected carcasses and form resistant spores affecting on exposure to air. This organism causes acute infectious disease in mainly wild and domestic herbivores. Humans are infected when they are exposed to infected animals carcasses or by handling infected animal products (hides and skin, wool, bone, flesh) or by inhaling anthrax spores from contaminated animal by-products and contaminated soil (Dixon et al., 1999; Thappa and Karthiklyan, 2001; Samad, 2008). Anthrax infection in human can occur in three forms: cutaneous which affects the skin; inhalation, which affects lungs and ingestion which affects the digestive tract.

Anthrax is endemic in Bangladesh and periodic outbreak of this malady in cattle have been a concern in this country from long time and Anthrax spore vaccine is used under field condition to control the disease. Published reports of anthrax in animals in Bangladesh date back to 1948 (Mohan and Ali, 1948). However, sporadic anthrax outbreaks in cattle and humans (Samad and Haque, 1986) and elephant (Mustafa, 1984) have been reported in Bangladesh. During 2009 to 2012, more than 25 outbreaks of anthrax have occurred simultaneously in both cattle and humans and more than 650 humans cases recorded in 15 districts during summer and monsoon seasons (April to October) from Bangladesh (Table 1). An investigation of 25 anthrax outbreaks in 414 human cases showed $378(91.30 \%)$ had cutaneous, $27(6.52 \%)$ had gastro-intestinal and $11(2.66 \%)$ had concurrent cutaneous and gastro-intestinal anthrax (Anon., 2011c). Simultaneous investigation of 190 anthrax suspected animals, cattle $(\mathrm{n}=126)$, goats $(\mathrm{n}=59)$, sheep $(\mathrm{n}=4)$ and buffalo $(\mathrm{n}=1)$ were identified, of which $126(66.32 \%)$ died for illness, $54(28.42 \%)$ slaughtered after illness onset and $10(5.26 \%)$ sold to the market (Anon. 2011c). Majority of the patients developed cutaneous anthrax had history of butchering sick animals, handling raw meat, contact with animal skin or were present at slaughtering sites (Herrimen,1012). Inadequate livestock vaccination coverage, lack of awareness of the risk of anthrax transmission from animal to humans, social norms and poverty contributed to these outbreaks (Chakraborty et.al., 2012).

This is the first time in Bangladesh that two human fatalities occurred among patients with anthrax about two weeks after onset of symptoms. These two death cases were in two different outbreaks, one in Bogra (70-yearold male) in July 2011 and the other in Tangail (40-year-old male) in August 2011 and both the patients had symptoms of concurrent cutaneous and gastro-intestinal anthrax. History showed that both of them participated in butchering sick animals (Anon. 2011c) and even all the human cases have been linked to slaughtered infected cattle. These were the largest anthrax outbreaks in the nation's history which resulted in the government declaring a red alert on $5^{\text {th }}$ September 2010 throughout the country. Eventually this 'red alert' was withdrawn 
after about a month $\left(7^{\text {th }}\right.$ October 2010) mainly considering the ensuing Eid-ul-Azha. Even after the 'red alert' withdrawal several simultaneous anthrax outbreaks in cattle and humans have been reported in the districts of Pabna and Sirajgong which might be due to inadequate and inappropriate control measures (Table 1). However, anthrax affected human patients had claimed that the disease could have broken out from the beef which they had purchased at a lower price than usual and a few days after consuming having the meat, most of them began to feel sick while others spotted small spots on different parts of the body. Some villagers are tainted or contaminated beef and had processed and/or come into contact with hides of anthrax-infected cattle.

Table 1. Reported anthrax outbreaks in animals and humans in Bangladesh

\begin{tabular}{|lllllll|}
\hline Year & Months & Districts & $\begin{array}{l}\text { No. of } \\
\text { outbreaks }\end{array}$ & $\begin{array}{l}\text { No. of animal } \\
\text { cases }\end{array}$ & $\begin{array}{l}\text { No. of human } \\
\text { cases }\end{array}$ & References \\
\hline \multirow{2}{*}{$1982-$ ‘ $83^{2}$} & - & Sirajgonj & 2 & $62 / 43(69 \%)^{*}$ & 27 & 154 \\
2084 & - & Dhaka Zoo & 1 & 1 elephant & 0 & 119 \\
& August & Pabna & 1 & - & 35 & 23,31 \\
2010 & Sept. \& Oct. & Sirajgonj & 2 & - & 20 & 23,31 \\
& April-June & Tangail & 4 & - & 44 & 31 \\
& July \& August & Sirajgonj & 5 & - & 141 & 31 \\
2010 & July-August & Pabna & 2 & - & 52 & 31 \\
$2009-10$ & July-Sept & Sirajgonj & - & 104 & 607 & 66 \\
2010 & August-Oct. & Bangladesh & 14 & 140 & 273 & $25,26,51$ \\
2011 & September & Lalmonirhat & 1 & 19 Cattle, 43 goats & 76 & 27 \\
& April & Pabna & 3 & - & 45 & 31 \\
& May & Sirajgonj & 5 & - & $28 *$ & 31 \\
& June & Bogra & 1 & - & 13 & 31 \\
2011 & June & Meherpur & 1 & - & $14 *$ & 31 \\
2012 & August & Tangail & 1 & - & $15 \#$ & 176 \\
& April-August & RMCH & - & - & 74 & 66 \\
& May \& June & Sirajgonj & 5 & - & 13 & 36 \\
& May & Kushtia & 1 & - & 14 & 36 \\
& June & Bogra & 1 & - & & 36 \\
\hline
\end{tabular}

\#All cases cured with 2 months oral ciprofloxacin combined with flucoxacillin for 2 weeks

*One man in Borga and one in Taingail died due to anthrax

Anthrax is an important disease of herbivorous animals and an endemic disease of cattle in Bangladesh. The districts of Pabna and Sirajgonj of Bangladesh are the main cattle rearing areas which are also recognized as 'anthrax belt.' The anthrax carcasses are usually thrown on the field. Eventually the carcass eating birds and animals consume them and break them open which result in the formation and release of highly resistant spores in presence of air (oxygen). Therefore, the anthrax spores normally exist in the soil of Bangladesh especially with higher prevalence in 'anthrax belt' areas. Livestock become ill after consuming contaminated grass, especially during or after the monsoon when water carries it to the surface. Slaughtering of sick animals, processing and handling their meat and hide and cooking and eating their meat may cause rapid disease transmission, even cooking does not deactivate the anthrax spores.

Anthrax infection occurs when spores enter the body and it is generally estimated that as low as 10 anthrax spores may initiate an infection and infection with a large number of spores $(>10,000)$ could be fatal (Ahmed et al., 2010; Kuddus, 2010). However, anthrax spores entering through skin wounds and eyes cause cutaneous anthrax indicated by dark (black) colored wounds which is not fatal if treated in time. For this reason no human with cutaneous anthrax has died but the outbreak has caused panic among people of Bangladesh. As a result, demand for beef and mutton has significantly plumped (nearly $90 \%$ in comparison to normal time). The sharp fall in the number of cattle slaughtered has drastically limited the supply of hides to the tanneries. The total population of animals slaughtered in whole Bangladesh per day is not estimated but about 5000 cattle are slaughter a day in the capital city, Dhaka but due to anthrax panic, this rate was reduced to less than 100 cattle per day. There are more than 200 tanneries in Bangladesh employing 70,000 people but millions of others such 
as farmers, dairy owners and traders are directly and indirectly dependent on the cattle industry. Bangladesh tannery companies earned US dollar 460 million in leather and leather goods through export annually. Due to anthrax crisis, the tannery industry owners lost more than 100 million US dollars during the month of anthrax outbreak.

Public education and awareness about anthrax, a complete and routine vaccination of cattle, quarantine and testing of all imported and slaughtered cattle, proper disposal of carcasses and contaminated materials, meat inspection by the Vets and meat sale by the licensed meat vendors would certainly help to control anthrax in Bangladesh.

\section{Tuberculosis}

Tuberculosis (TB) is caused by acid-fast bacillus of the Mycobacterium and the most common species are $M$. tuberculosis (man, non-human primates, cattle, dogs, swine, psittacines), M. bovis (cattle, dogs, swine, man) and $M$. avium (birds, swine, sheep). All the three species are capable of causing disease in man although $M$. tuberculosis is by far the most common. Human tuberculosis is the world's second commonest cause of death from infectious disease after HIV/AIDS. It is estimated that 1.7 million died and 9.4 million new cases of human TB emerged in the world in 2009, of which the majority were in Asia and Africa. Of the people who died of TB in 2008, it is estimated that 400,000 were infected with HIV. Bangladesh ranks $6^{\text {th }}$ among 22 most TB affected countries $(225 / 100,000$ cases in 2009) in the world, with 300,000 new cases and 70,000 deaths reported every year (WHO, 2005). Nationwide tuberculosis prevalence survey in Bangladesh 2007 to 2009 detected an overall adjusted prevalence $79.4 \%$ per 100,000 persons $\geq 15$ years and higher in males and rural residents (Anon. 2010e)

Bovine tuberculosis (BTB), which is caused by M. bovis, is one of the most important zoonotic diseases worldwide. Of the 176 countries reported tuberculosis, 4 indicated BTB to be an exceptional occurrence, 62 reported as low sporadic occurrence, 21 reported it as enzootic, 3 reported a high occurrence and 7 stated that the disease exists but the occurrence is unknown (Samad, 2008). Between 1994 and 2000, 1931 human cases of culture-positive TB have been identified in France, of which 129 (6.7\%) infected with M. bovis and 1802 with $M$. tuberculosis (Bob, 2011; Huq and Moyenuddin, 1984; Samad, 2008).

BTB mainly affects cattle but also affect man and other domestic and wild species. BTB in humans caused by M. bovis is clinically indistinguishable from TB caused by M. tuberculosis. Globally, human TB due to M. bovis has recently been estimated to be the cause of 5 to $10 \%$ of all human cases. About $25 \%$ of patients reported with children and the main site of disease has been reported to have occurred in extra-pulmonary (cervical and mesenteric nodes, the peritoneum and gastro-intestinal tract) in 53\% patients (Samad, 2008). In developed countries, animal TB control and elimination programs, together with milk pasteurization have drastically reduced the incidence of disease caused by M. bovis in both cattle and humans, whereas in developing countries, animal TB is widely distributed, control measures are not applied or are applied sporadically and pasteurization is rarely practiced (Cosivi et al., 1998).

The reports on the prevalence of BTB in Bangladesh revealed 2.10\% zebu and $7.80 \%$ cross-bred cattle had positive reactors to tuberculin test (Samad and Rahman, 1986). Recently $27.5 \%$ breeding bulls of Central Artificial Insemination Center, Savar, Dhaka (Islam et al., 2007) and more recently Rahman and Samad (2008) reported that $30 \%$ prevalence of tuberculosis in Red Chittagong cattle (Table 2). It appears from the review of literature that about $4.5 \%$ of the tuberculosis positive cattle could excrete tuberculosis organism in their milk (Samad, 2008).

Although there is a testing and treatment program of HTB at national level in fact there is no such testing and culling program of BTB at national level in Bangladesh. People have close contact with animals and they often consume raw milk or unpasteurized milk and those who consumed poorly heat-treated meat are at high risk. Animal farm workers, veterinarian, abattoir workers and farmers have a high occupational risk due to close contact with infected animals. Even poor villagers often share their houses with animals for sleeping which is also a risk. 
Table 2. Prevalence of major bacterial zoonotic diseases in Bangladesh

\begin{tabular}{|c|c|c|c|c|c|c|c|}
\hline \multicolumn{2}{|c|}{ S/NDisease } & \multirow[t]{2}{*}{ Hosts } & \multirow{2}{*}{$\begin{array}{l}\text { No. of } \\
\text { population } \\
\text { tested }\end{array}$} & \multirow[t]{2}{*}{ Types } & \multirow[t]{2}{*}{ Test used } & \multirow{2}{*}{$\frac{\text { Positives }}{\text { No. (\%) }}$} & \multirow{2}{*}{$\begin{array}{l}\text { Reference } \\
\text { numbers }\end{array}$} \\
\hline & & & & & & & \\
\hline \multirow[t]{5}{*}{ (1) } & Anthrax & Cattle & 62 & Clinical & Culture & $43(69.0)$ & 154 \\
\hline & & Humans & 27 & Clinical & Culture & $27(100)$ & 154 \\
\hline & & Elephant & 01 & Clinical & Culture & $01(100)$ & 119 \\
\hline & & Cattle & 190 & Clinical & Culture & $>100$ & Table 1 \\
\hline & & Humans & $>650$ & Clinical & Culture & $>650$ & Table 1 \\
\hline \multirow[t]{2}{*}{ (2) } & Tuberculosis & Cattle & 3036 & A. healthy & Tuberculin & $172(5.67)$ & $98,143,155$ \\
\hline & & Cattle & 30 & A. healthy & Ab test kit & $0930.0)$ & 143 \\
\hline \multirow[t]{6}{*}{ (3) } & Brucellosis & Humans & 526 & A. healthy & Sero-tests & $165(12.36)$ & $118,120,140,141$ \\
\hline & & Cattle & 2485 & A. healthy & Sero-tests & $233(9.38)$ & $\begin{array}{c}3,123,129,136 \\
138,139\end{array}$ \\
\hline & & Goats & 350 & A. healthy & Sero-tests & $77(21.85)$ & 141 \\
\hline & & Sheep & 362 & A. healthy & Sero-tests & $13(03.59)$ & 151 \\
\hline & & Buffaloes & 288 & A. healthy & Sero-tests & $20(6.96)$ & 130 \\
\hline & & Stray dogs & 30 & A. healthy & Sero-tests & $03(10.00)$ & 182 \\
\hline (4) & Salmonellosis & Water & 100 & RPTT water & Culture & $0-60(0-60)$ & Table 3 \\
\hline (5) & Campylobacteriosis & Humans & 300 & A. healthy & Fecal test & $58(19.33)$ & $58,59,71,181$ \\
\hline (6) & Leptospirosis & Humans & $359 *$ & Clinical & RT-PCR & $63(17.55)$ & 35 \\
\hline
\end{tabular}

A = Apparently $\quad$ RPTT $=$ River, Pond, Tape, Tube-well $\quad$ *Dengue negative sera

\section{Brucellosis}

Brucellosis remains one of the most common zoonotic diseases worldwide with more than 500,000 human cases reported annually. The disease occurs worldwide in both animals and humans, except in those countries where bovine brucellosis has been eradicated by using vaccination and/or method of screening and culling (Samad, 2008). Five out of the nine known Brucella species can infect humans and the most pathogenic and invasive species for human is Br. melitensis (sheep, goats), followed in descending order by Br. suis (swine), Br. abortus (cattle, sheep) and Br. canis (dogs), and accordingly, Br. melitensis, Br. suis and Br. abortus are listed as potential bio-weapons (Seleem et al., 2010). It is generally transmitted to consumers through raw milk and milk products (cheese), but the human-to-human transmission of the infection does not occur. The importance of brucellosis is not known precisely, but it can have a considerable impact on human and animal health, along with wide socio-economic impacts, especially in countries where rural income relies largely on livestock breeding and dairy products. Some specific occupational groups including farm workers, Veterinarians, animal caretakers and butchers are considered at higher risk to brucellosis. Brucellosis in humans is characterized by extreme weakness, joint and muscle pain, headache, undulant fever, hepatomegaly, splenomegaly and night sweats. Brucellosis in animals, mainly affects reproduction and fertility, causes late abortion, reduces survival chances of newborns and reduces milk yield (Islam et al., 1983; Rahman et al., 2006; Samad, 2008). When the incidence of brucellosis is controlled in the animal reservoirs, there is a corresponding and significant decline in the incidence in humans.

\section{Salmonellosis and Colibacillosis}

Salmonellosis (Salmonella food poisoning and enteric paratyphosis) is a public health concern because most of the strains of Salmonellae are potentially pathogenic to humans and animals worldwide. There are over 1800 food-poisoning serotypes of Salmonella exist in the world and about 5 million human cases of salmonellosis are diagnosed annually in the United States (Bob, 2011) and problem may be more severe in Bangladesh.

Salmonellae are common commensalisms of mammals, birds, reptiles and are excreted in feces. Host-adapted strains may cause disease like $S$. dublin in cattle, S. pullorum in chickens, but most human food-poisoning Salmonellae do not cause clinical disease in animals. Infection in animals is maintained by recycling slaughterhouse waste as animal feed, fecal oral spread and fecal contamination of hatching egg (Borhanuddin et al., 1986). Transmission occurs when organisms introduced into the kitchen in poultry carcasses, meat or 


\section{A. Samad}

unpasteurized milk, multiply in food owning to inadequate cooking, cross-contamination of cooked foods and inadequate storage. Transmission by direct contact and indirect transmission via contaminated food and water (Table 3) with feces and contaminant of sewage. The incubation period varies from 12 to 72 hours in humans and 1 to 5 days in animals. Typically, gastro-enteritis (watery diarrhea) for about 10 days, leading to dehydration, colic and low-grade fever and occasionally septicemia and abscess in humans are reported. Sub-clinical infection is common in animals and many animals may be intermittent or persistent carriers. Cows may suffer with fever, diarrhea and abortion but calves undergo epizootic outbreaks of diarrhea with high mortality. Infected small ruminant and birds usually show no signs of infection. The causative agent of colibacillosis, Escherichia coli isolated form humans and animals have been characterized in Bangladesh (Ali et al., 1998).

Salmonella enteritidis is one of the most important bacterium which is usually transmitted through infected eggs which can pose a health risk to human if exposed. It appears that birds mainly acquire the infection from the environment and that infected birds play a relatively small role in the transmission of infection to animals and humans. Symptoms appear similar to food poisoning such as gastro-enteritis (diarrhea).

Public health concerns and the potential for food borne zoonotic transmission have made Salmonella the subject of numerous international, national and local surveillance programs.

Table 3. Bacterial status of water in Bangladesh (137)

\begin{tabular}{|c|c|c|c|c|c|}
\hline \multirow[t]{2}{*}{$\mathrm{S} / \mathrm{N}$} & \multirow{2}{*}{$\begin{array}{l}\text { Sources of } \\
\text { samples }\end{array}$} & \multirow{2}{*}{$\begin{array}{l}\text { No. of } \\
\text { samples } \\
\text { tested }\end{array}$} & \multicolumn{2}{|c|}{ Species of bacteria identified, No. (\%) } & \\
\hline & & & Salmonella spp.* & Escherichia coli & \\
\hline (1) & River water & 100 & $25(25.00)$ & $60(60.00)$ & * Salmonella species \\
\hline (2) & Pond water & 100 & $10(10.00)$ & $40(40.00)$ & include: \\
\hline (3) & Tape water & 100 & $04(04.00)$ & $15(15.00)$ & S. typhimurium \\
\hline (4) & Tube-well water & 100 & $00(00.00)$ & $02(02.00)$ & S. enteritidis \\
\hline
\end{tabular}

\section{Campylobacteriosis}

Campylobacteriosis is an important zoonotic disease, associated with bacterial gastro-enteritis and may be responsible for as many as 400 to 500 million human cases emerging worldwide annually. Although the genus Campylobacter is composed of 17 described species, clinical disease is primarily with Campylobacter jejuni and C. coli. Microbio-chemical investigation of 300 diarrheic stool samples of children in Bangladesh showed 58 (19.33\%) had Campylobacter infection (Table 2), of which 40 (68.97\%) isolates had C. jejuni, 5 (8.62\%) had C. coli infection and the $13(22.41 \%)$ remain unidentified (Talukder et al., 2008). The $C$. jejuni has been identified to be associated with predominantly watery diarrhea and isolated in frequencies varying from 17 to $26 \%$ in Bangladesh (Datta et al., 2003; Debnath et al., 1986; Haq and Rahman, 1991; Talukder et al., 2008). Though distributed worldwide the incidence is high in developing countries due to inadequate personal and domestic hygiene. It is a commensal organism which is isolated from 3 to $100 \%$ apparently healthy animals and birds. The organism is viable for three weeks in feces and milk, four weeks in water and five weeks in urine at $40{ }^{\circ} \mathrm{C}$. This organism is shed in the feces for at least six weeks after infection.

Transmission is by the feco-oral route, through contamination of food and water, and direct contact with infected fecal material. Poultry and cattle are the reservoirs for human infection, which is acquired by ingesting contaminated raw milk, under-cooked chicken or other food contaminated in the kitchen. Disease in humans is characterized by acute gastro-enteritis (diarrhea) with or without blood, abdominal pain and fever, and also may cause pseudo-appendicitis and rarely septicemia and arthritis.

\section{Leptospirosis}

Leptospirosis is a zoonotic disease, caused by pathogenic leptospires belong to the species Leptospira interrogans, which is sub-divided into more than 200 sero-vars. The main natural reservoirs for human infection vary with serovar: L. canicola in dogs, L. hardjo in cattle, L. pomona in swine, and L. icterohaemorrhahiae in rats. Infection usually results when water or soil contaminated with the urine of an infected animal comes in contact with human skin or mucous membrane. Clinical manifestations of leptospirosis can range from a selflimited febrile syndrome to a fatal illness, characterized by hemorrhage, renal failure and jaundice. So far, there is evidence on the occurrence of leptospirosis in Bangladesh (Anon., 2011g) which was conducted in connection 
to dengue fever and $17.55 \%$ of dengue-negative patient's sera showed positive reaction for leptospirosis (Table 2). It has also been found that the case fatality rate among leptospirosis patients (5\%) was higher than among dengue fever patients $(1.2 \%)$.

Although leptospirosis has been reported in most of the neighboring countries of Southeast Asia, the work on this disease is not done in Bangladesh where diagnostic tests for leptospirosis are not available. However, environmental factors such as floods, humidity and water contamination are amenable to the spreading of the disease in both man and animals in Bangladesh.

\section{Major zoonotic viral diseases}

There are more than 5,000 viruses known to man and they are evolving every day. Some important zoonotic virus diseases are associated with human deaths globally every year. Most of the statistics on the morbidity and mortality rates are taken from WHO reports.

\section{Avian and swine flu}

Much has been made in the press of the recent 'avian flu' and 'swine flu' pandemic, caused by the spread of the H5N1 and H1N1 virus respectively. But the truth is, influenza has been a prolific killer for centuries. The symptoms of influenza were first described more than 2,400 years ago by Hippocrates. Pandemic generally occur three times a century, and can cause millions of deaths. The most fatal pandemic on record was the Spanish flu outbreak in 1918, which caused between 20 million and 100 million deaths.

Avian influenza (AI) is an important emerging infectious disease, caused by highly pathogenic avian influenza (HPAI) virus A affecting birds and mammals including humans. A new strain of HPAI A (H5N1) virus has been circulating among birds in Asia since 1996. The first officially announced AI outbreak caused by H5N1 in Bangladesh occurred in 27 March 2007. Since then the virus has spread to 51 out of 64 districts and more than 480 outbreaks have been officially reported and more than two million birds have been culled. The status of AI outbreaks in chickens (Biswas et al., 2008) and its risks in backyard chickens (Biswas et al., 2009) has been reported from Bangladesh (Table 6). The country's poultry sector is currently worth Tk. 250 billion (US \$ 3.5 billion) and AI has cost Tk. 55 billion (US \$ 757.9 million) due to outbreaks of AI in 2007. Bangladesh is a high risk country for an influenza pandemic because of its dense human population, widespread backyard poultry raising and endemic $\mathrm{H} 5 \mathrm{~N} 1$ infection in poultry.

Since 2003, the WHO has recorded (up to August 2012) 598 cases of human infection with Avian influenza virus of which 352 have died in the world, leading to great concern that the H5N1 avian influenza virus could cause a devastating pandemic if it adapts to spread easily among humans (WHO, 2012a). So far, about six human cases of H5N1 have been reported since its first appearance in 2007 from Bangladesh (Table 4).

Bangladesh has about 220 million chickens and 37 million ducks, of which 185 million are backyard poultry with minimum bio-security (Biswas et al., 2009). About 21 species of migratory birds capable of carrying the virus visit the country annually every winter. In addition to chicken, this disease has been recorded in ducks, pigeons and non-migratory wild birds (mostly crows) in Bangladesh (Baqi and Khyam, 2011).

These zoonotic diseases from 2003 to August 2012, a total of 598 human cases have been reported from the world, of which 352 persons died (WHO, 2012a). Between 2005 and 2010, H5N1 HPAI virus spread rapidly to over 60 countries on three continents. So far, the AI control program has been implemented through 170 projects, actively involving 130 countries. In Bangladesh a number of projects have been implemented and financed by FAO, World Bank, ADB with millions of US dollars, mostly for strengthening disease surveillance, virus elimination and communication campaigns. But the recent FAO report reveals that AI virus remains firmly entrenched and the virus elimination effort faces three major obstacles in Bangladesh which include the structure of the poultry industry, the quality of Veterinary and poultry production service and the level of commitment by all sectors. Therefore, AI in Bangladesh remains a significant threat to avian health and welfare, public health, agricultural productivity, economics and livelihoods of the poorest farmers. 


\section{A. Samad}

Table 4. Confirmed human cases of Avian influenza virus (H5N1) infection in humans in Bangladesh

\begin{tabular}{|c|c|c|c|c|}
\hline $\mathrm{S} / \mathrm{N}$ & Year & Cases & Description & References \\
\hline (1) & 2008 & 01 & $\begin{array}{l}\text { The first human case of HPAI A (H5N1) virus was recognized in Bangladesh in a } 16 \\
\text { month-old boy from the capital city Dhaka on } 22 \text { January } 2008 \text {. He developed fever } \\
\text { and difficulty breathing but recovered. The most likely source of H5N1 virus exposure } \\
\text { was from a chicken that was slaughtered in his household. }\end{array}$ & 19,21 \\
\hline (2) & 2011 & 02 & $\begin{array}{l}\text { The } 2^{\text {nd }} \text { and } 3^{\text {rd }} \text { cases of AI in humans in Bangladesh were reported in } 2011 \text {. The } 2^{\text {nd }} \\
\text { case was diagnosed in a } 31 \text {-month-old child who has presented with a history of cough } \\
\text { and fever in Dhaka on } 15^{\text {th }} \text { March } 2011 \text {, confirmed by real-time RT-PCR. } \\
\text { The } 3^{\text {rd }} \text { case of Avian influenza was detected in the Kamalapur area of the capital Dhaka. }\end{array}$ & 22,30 \\
\hline (3) & 2012 & 03 & $\begin{array}{l}\text { The } 4^{\text {th }} \text { case was a } 40 \text { year-old male from Dhaka city who was identified as part of the } \\
\text { live bird market surveillance system on } 26 \text { February } 2012 \text {. The case was presented with } \\
\text { cough and recovered. } \\
\text { Following that report, two more cases were reported: a } 26 \text { year-old and an } 18 \text { year-old } \\
\text { male who presented with history of cough from the same live market but they were } \\
\text { recovered. }\end{array}$ & 189-192 \\
\hline
\end{tabular}

\section{Rabies}

Rabies is a highly fatal viral infection of the central nervous system which occurs virtually in all warm blooded animals and humans and is transmitted by the bite of affected animals. Dogs, cats, jackals and other wild animals are the carriers of this infection but in Bangladesh most of the rabies cases in both humans and animals are due to dog bites. Rabies virus laden saliva via bite, scratch or abrasion. Rabid dogs shed virus in saliva 5 to 7 days before showing clinical signs, whereas cat does so for only three days before signs (Bob, 2011). Among the domestic animals, cattle and goats are most commonly affected with rabies in Bangladesh.

Rabies is being considered as a priority zoonosis in Bangladesh. Sporadic incidence occurs in all parts of the country throughout the year. Bangladesh has human population of about 160 million, 22.90 million cattle and 36.90 million goats. No estimate has been made of the dog population but there is a large number of stray dogs compared to lower number of pet dogs in Bangladesh have made rabies infection a more common than elsewhere.

Almost all human deaths caused by rabies originated from Asia and Africa (Samad, 2008). There are an estimated 55,000 human death annually from rabies worldwide with about 31,000 in Asia and 24,000 in Africa. According to the Bangladesh Government reports, dogs bit nearly 100,000 people and at least 2,000 died of rabies in 2009, the highest per capita rate in the world. The number of deaths in animals is unknown but probably the higher than the figure for human cases. Approximately, 50,000 human beings and 8,000 domestic animals received post-exposure vaccine treatment due to dog bite in Bangladesh annually. However, many bites are not reported due to ignorance and lack of facilities (Table 6). The Dhaka City Corporation alone kills up to 20,000 stray dogs a year and this stray dog culling program is only limited to the City corporation in the country. In addition, approximately 5000 pet dogs are vaccinated with locally produced vaccine. Epidemiological studies of rabies in Bangladesh are very limited (Ali et al., 1982; Biswas et al., 1996) to formulate an effective control program.

\section{Nipah virus infection}

Nipah virus (NiV) infection is an important zoonotic emerging infectious disease (EID) that causes fatal disease in humans, characterized primarily by fever and encephalitis. Nipah virus is a member of the genus Henipavirus, a new class of virus in the family Paramyxoviridae. Nipah virus was first recorded in 1998 when it caused an outbreak of neurological and respiratory disease on pig farms in Peninsular Malaysia, resulting in 257 human cases, including 105 human deaths and the culling of one million pigs and then linked to fruit bats (Luby et al., 2009a). In Singapore, 11 cases including one death, occurred in abattoir workers exposed to pigs imported from the affected Malaysian farms. The name 'Nipah' is taken after the place, Kampong Nipah in Negeri Sembilan where the virus was first isolated from humans in that area.

The recurrent outbreaks of NiV infection have been recognized since 2001 in Bangladesh (Gurley et al., 2007; Hsu et al., 2004; Luby et al., 2009a) and human beings infected with NiV as a result of consuming date palm sap that had been contaminated by infected fruit bats (Pteropus giganteus) that lives in Bangladesh and the blood 
samples of this bats and the neighboring Indian bats have antibodies to NiV infection (Hsu et al., 2004; Harcourt et al., 2005; Luby et al., 2009b). Accordingly, the Nipah outbreak sites lie within the range of Pteropus giganteus species of bats. Apart from pigs and humans, Nipah virus is also prevalent in other domestic animals like horses, goats, sheep, cats and dogs. Since 2001, human outbreaks and clusters of cases have been reported periodically in Bangladesh (Table 5).

Table 5. Morbidity and mortality caused by Nipah virus in humans in Bangladesh

\begin{tabular}{|llllll|}
\hline S/L & Period & District & Morbidity & Mortality & Reference No. \\
\hline 1 & April to May 2001 & Meherpur & 13 & $09(69)$ & 16,17, \\
2 & January 2003 & Naogaon & 12 & $08(67)$ & 18, \\
3 & January to February 2004 & Manikganj and Rajbari & 42 & $14(33)$ & 20, \\
4 & February to April 2004 & Faridpur & 36 & $27(75)$ & 24, \\
5 & January 2005 & Tangail & 12 & $11(92)$ & 48, \\
6 & January to February 2007 & Thakurgaon & 07 & $03(43)$ & 70, \\
7 & March to April 2007 & Kushtia & 08 & $05(63)$ & 81, \\
8 & February to March 2008 & Manikgonj and Rajbari & 09 & $08(89)$ & 111,112, \\
9 & April 2008 & Shatkira and Jessore & 02 & $01(50)$ & 113, \\
10 & January 2010 & Faridpur & 08 & $07(88) *$ & 117, \\
11 & February 2011 & Lalmonirhat & 24 & $17(71)+21 * *$ & 186 \\
& Total: & & $\mathbf{1 7 3}$ & $\mathbf{1 1 0}(\mathbf{6 3 . 5 8 \% )}$ & \\
\hline
\end{tabular}

*During March, one physician of Faridpur Medical College Hospital carrying for confirmed Nipah case died (76)

**Death of 21 school children caused by Nipah virus due to consumption of uncooked fruits and fruit products contaminated with urine and saliva from infected fruit bats.

Review of literature of all the human NiV infection recognized in Bangladesh revealed that the fruit bats are the reservoir host in all the identified 23 introductions of $\mathrm{NiV}$ into human populations in Central and Northwestern Bangladesh from 2001 through 2011. So far, 173 human cases of NiV infection have been identified in Bangladesh, of which 110 (63.58\%) died (Table 5). The primary pathways of transmission from bats to people in Bangladesh are through contamination of raw date palm sap by bats with subsequent consumption by humans and through infection of domestic animals, presumably from consumption of food contaminated with bat saliva or urine with subsequent transmission to people.

It was observed that the illness onset occurred from December through May but not every year. Although fruit bat is the main natural reservoir host of NiV in Bangladesh but about 51\% $(n=62)$ Nipah cases were recognized as person-to-person transmission (Blum et al., 2009; Luby et al., 2009a), where clinical signs developed 5 to 15 days after close contact with another Nipah case-patient. In addition, risk factors of Nipah virus encephalitis in Bangladesh have been described (Montgomery et al., 2008). Therefore, efforts to prevent transmission should focus on decreasing bat access to date palm sap and reducing family members' and friends' exposure to infected patients' saliva.

\section{Japanese encephalitis}

Japanese encephalitis (JE) is a vector-borne zoonotic disease, caused by JE virus of the genus Flavivirus and family Flaviviridae. This disease was first emerged in Japan in the 1870 s, followed by isolation of the causative virus in 1935. Most extensive epidemics of JE have occurred in Japan and Korea, in 1949 when almost 2500 deaths have been reported in South Korea due to JE. Then it has spread across Asia and now recognized as worldwide distributed but it is most important cause of epidemic encephalitis in over 25 countries including Bangladesh (Hussain et al., 2004). An estimated three billion people live in countries where the JEV is endemic and the annual incidence of the disease is 35,000 to 50,000 cases and 10,000 to 15,000 deaths annually (Erlanger et al., 2009).

Vaccination programs, increased living standard and mechanization of agriculture are key factors in the decline in the incidence of this disease in Japan and South Korea. However, transmission of JE is likely to increase in Bangladesh (Table 6) and other countries because of population growth, intensified rice farming, pig rearing and lack of vaccination program and surveillance (Erlanger et al., 2009). 


\section{A. Samad}

Japanese encephalitis has been recognized in Bangladesh since an outbreak in 1977 in a rural area in Mymensingh. A prospective hospital based surveillance study carried out by ICDDR'B, CDC, USA beginning June 2003 in Dhaka, Mymensingh and Rajshahi to find out the causes of encephalitis proved that are 6\% patient who were admitted to the hospital with the signs and symptoms of encephalitis patients had JEV infection (Hussain et al., 2004).

Analysis of the Rajshahi Medical College Hospital (RMCH) data showed $12.38 \%$ encephalitis patients had JEV infection (Hussain et al., 2004). It also appears from another report that 20 (4\%) of 492 cases had laboratory evidence of recent JEV infection of which two patients died, $5(33 \%)$ patients had physical disability and 7 (47\%) patients reported cognitive difficulties (Table 6). These results indicate that the JE is an emerging cause of encephalitis in Bangladesh (Khan et al., 1981).

The JEV is transmitted in a zoonotic cycle among mosquitoes and vertebrate amplifying hosts, chiefly pigs and wading water birds like herons and egrets. JEV has been isolated from 10 different species of Culex, 4 species of Anopheles, and 8 species of Mansonia mosquitoes, but the most important human infection is spread by Culex triaeniorrhynchus and Culex vishnui groups which breeds in pools of stagnant water such as rice paddy field.

Our study on the sero-prevalence of JE in pigs showed 38.19\% pigs had JEV infection in Bangladesh (Biswas et al., 1986). Pigs are the most important natural host for transmission to humans in rural areas. They have also prolonged and high viremia and produce many offspring. JEV does not typically cause encephalitis in these natural hosts, although abortions occur in pregnant sows $(38.19 \%)$. The origin, evaluation and control methods of Japanese encephalitis have been described in Southeast Asia (Solomon, 2006; Solomon et al., 2003).

Table 6. Prevalence of major viral zoonotic diseases in Bangladesh

\begin{tabular}{|c|c|c|c|c|c|c|c|}
\hline \multirow[t]{2}{*}{$\mathrm{S} / \mathrm{N}$} & \multirow[t]{2}{*}{ Disease } & \multirow[t]{2}{*}{ Hosts } & \multirow{2}{*}{$\begin{array}{l}\text { No. of } \\
\text { population } \\
\text { tested }\end{array}$} & \multirow{2}{*}{$\begin{array}{l}\text { Types of } \\
\text { population }\end{array}$} & \multirow[t]{2}{*}{ Test used } & \multirow{2}{*}{$\begin{array}{c}\text { Positives } \\
\text { No. (\%) }\end{array}$} & \multirow{2}{*}{$\begin{array}{l}\text { Reference } \\
\text { numbers }\end{array}$} \\
\hline & & & & & & & \\
\hline \multirow[t]{2}{*}{ (1) } & \multirow{2}{*}{ Avian influenza } & Chickens & $>2$ million & Culled & Lab test & $>2$ culled & $21,22,89$ \\
\hline & & Humans & 06 & Clinical & Lab test & 06 & Table 4 \\
\hline \multirow[t]{8}{*}{ (2) } & \multirow{8}{*}{ Rabies } & Humans & 100,000 & Dog bite & Field test & $2000(2.0)^{*}$ & 11,151 \\
\hline & & Dogs & 100 & Stray dogs & Serum (NT) & $7(7.00)$ & 11,45 \\
\hline & & & & & Saliva (FAT) & $0(0.00)$ & 11,45 \\
\hline & & & & & Brain (FAT) & $1(0.00)$ & 11,45 \\
\hline & & Cattle & 2608 & Carcass & Field test & $43(1.65)$ & 99 \\
\hline & & Buffalo & 2266 & Carcass & Field test & $25(1.10)$ & 99 \\
\hline & & Sheep & 239 & Carcass & Field test & $03(1.25)$ & 99 \\
\hline & & Goat & 917 & Carcass & Field test & $18(1,96)$ & 99 \\
\hline (3) & Nipah virus infection & Human & 173 & Clinical & Lab tests & $110(63.58)^{*}$ & Table 5 \\
\hline \multirow[t]{4}{*}{ (4) } & \multirow[t]{4}{*}{ Japanese encephalitis } & Pigs & 288 & A. healthy & HIT & $110(38.19)$ & 44 \\
\hline & & Cattle & 060 & A. healthy & HIT & - ve & 44 \\
\hline & & Dogs & 052 & A. healthy & HIT & - ve & 44 \\
\hline & & Humans & 597 & Patients & IgM ELISA & $26(4.36)$ & 82,88 \\
\hline \multirow[t]{7}{*}{ (5) } & \multirow[t]{7}{*}{ Rotavirus } & Buffalo & 242 & Diarrheic & ELISA & $29(12.00)$ & 156 \\
\hline & & calves & 108 & Non-diarrheic & ELISA & $03(03.00)$ & 156 \\
\hline & & Kids & 484 & Diarrheic & PAGE-SS & $42(08.68)$ & 60 \\
\hline & & Calves & 402 & Diarrheic & PAGE-SS & $176(43.78)$ & 9,133 \\
\hline & & Broiler & 251 & Diarrheic & PAGE-SS & $033(13.15)$ & 103 \\
\hline & & Humans & 220 & Adult diarrheic &,+ ELISA & $012(5.45)$ & 5,167 \\
\hline & & Children & 26668 & Diarrheic & $\begin{array}{l}\text { ELISA+ } \\
\text { PAGE-SS }\end{array}$ & $5851(21.94)$ & $\begin{array}{l}9,67,132, \\
167\end{array}$ \\
\hline (6) & Contagious echthyma & Goats & 05 & Patient & Clinical & $005(100)$ & 150 \\
\hline (7) & Dengue fever & Humans & 1356 & Febrile patients & $\begin{array}{l}\text { ELISA , } \\
\text { RT-PCR }\end{array}$ & $566(41.74)$ & $\begin{array}{l}13,14,52,80 \\
122.146\end{array}$ \\
\hline
\end{tabular}

*Died 


\section{Rotavirus}

Rotavirus infection is caused by RNA virus of the family Reoviridae, mainly associated with gastro-enteritis (diarrhea) in humans and animals worldwide. This virus was first identified in 1973 and currently WHO estimates that this virus causes deaths of more than half a million (about 611,000/year) children annually. In fact, by the age of five, virtually every child on the planet has been infected with the virus at least once. Immunity builds up with each infection, so subsequent infections are milder where inadequate healthcare is limited the disease if often fatal. Of the seven groups (A to G) known, group A rotavirus causes more than $90 \%$ of human infection and group B cause diseases in humans and pigs in China, whereas $\mathrm{C}$ is distributed worldwide. There are at least 15 different serotypes of rotavirus, $14 \mathrm{G}$ serotypes are based on $\mathrm{G}$ protein and there are $20 \mathrm{p}$ serotypes based on p proteins (Dey et al., 2009; Rahman et al., 2007).

The prevalence of rotaviruses has been reported in buffalo calves (Samad and Ahmed, 1990), cow calves (Selim et al., 1991; Ershaduzzam et al., 1992; Rahman et al., 1992; Alam et al., 1994), kids (Dey et al., 2007), broiler birds (Islam et al., 2009) and human adult (Sanekata et al., 2003) and children (Ahmed et al., 1989; Alam et al., 1994; Kilgore et al., 1996; Ahmed et al., 1991; 1999; Alam et al., 1999; Amim et al., 1999; Sanekata et al., 2003; Islam et al., 2009) from Bangladesh (Table 6).

Rotaviruses cause gastro-enteritis in man and animals, and they are generally species-specific but cross-species transmission with man or animal rotaviruses have been confirmed. Several case studies have indicated infection of humans by animal rotaviruses. Comparison of genetic sequences between human and animal rotaviruses often reveals close identity. Surveillance of circulating rotaviruses in the human population has revealed the presence of several uncommon genotypes. Many of these have been found in domestic animals and it is possible that they arose in the human population through zoonotic transmission (Cook et al., 2004). The low incidence of uncommon strains would suggest that such transmission or at least the establishment of an animal rotavirus or a human / animal reassortment virus in the human population does not happen with any great frequency. However, millions of people will be exposed year on year to animal rotaviruses due to close contact with animals in farming communities and rural peoples. There may be a continual input of rotavirus strains or sequences in the human population from the animal population albeit at a very low level.

\section{Contagious ecthyma and Foot-and-mouth disease}

Contagious ecthyma (Orf) is a zoonotic disease that primarily affects in sheep and goat worldwide. Although the clinical occurrence of this disease in goats has been reported from Bangladesh (Samad, 2000a), its transmission from animals to humans has not yet been documented locally. This virus disease is caused by Contagious ecthyma virus (CEV) which belongs to the genus Parapoxvirus of the Family Poxviridae. This virus is highly resistant and persists for many years and can be transmitted easily from animals to man via contact. Disease in goats is characterized by lesions at the oral commissars and then spread to the muzzle and nostrils, then buccal mucosa, whereas in humans it appears as large painful nodules usually distributed in the hands, arms or face and weeping surfaces (Samad, 2008).

Foot-and-mouth disease is an endemic disease mainly affecting ruminants in Bangladesh and severe outbreaks are mostly recorded in cattle (Islam and Samad, 1998). Although it has been reported as one of the important zoonotic disease elsewhere (Samad, 2008), its zoonotic importance has not been evaluated under local conditions.

\section{Dengue fever and Dengue hemorrhagic fever}

Dengue fever (DF) and Dengue hemorrhagic fever (DHF) are the mosquito-borne viral diseases of humans, caused by four antigenically distinct but closely related Dengue virus transmitted primarily by Aedes aegypti. DHF, the severe form of the disease is endemic in Southeast Asia resulting in frequent hospitalizations and deaths of humans. Monkeys may become infected with Dengue virus but are mostly sub-clinical and they act as a source of infection for mosquitoes during the viremic phase (Samad, 2008). Dengue is now endemic in more than 100 countries including Bangladesh (Yunus et al., 2001; Wagatsuma et al., 2004), especially tropical and subtropical regions, predominantly in urban and peri-urban areas. WHO estimates that a whopping 2.5 billion people (two fifths of the world's population) are now at risk from Dengue. It puts the total number of infections at around 50 million cases of dengue infection worldwide every year.

Dengue was first reported in Bangladesh in 1964 and the outbreak cause is known as Dhaka fever (Aziz et al., 1967; 2002). Subsequently reports (Russell et al., 1966; Gaidamovich et al., 1980; Amim et al., 1999; Hossain et al., 2003) suggested that DF may have been occurring sporadically in Bangladesh between 1964 and the 


\section{A. Samad}

outbreak that began in 2000 (Yunus, 2000; Aziz et al., 2002; Rahman et al., 2002) during which predominantly DENV-3 was recovered from patients (Yunus, 2000) during which 5,551 cases and 93 Dengue-related deaths were reported (Amim et al., 2000; Ahmed et al., 2001).

Dengue causes more illness and death than any other arboviral infection in the world. DHF is caused by Dengue type-3 virus (Podder et al., 2006) and is characterized by fever, hemorrhagic tendency, thrombocytopenia and evidence of plasma leakage. The first outbreak highlights the geographic expansion of DHF in Bangladesh, where classic DF outbreak started in 2000. In addition to fever, it may be characterized by myalgia $(84.5 \%)$, headache $(82.5 \%)$, arthralgia $(68.0 \%)$, lethargy $(80.4 \%)$ and retro-orbital pain $(49.5 \%)$ and rash (Pervin et al., 2004). Results of the different inland reports on DF (Table 6) indicate that many dengue cases go undiagnosed and physicians obviously are not very much acquainted with this disease of public health importance. Disease surveillance, vector surveys and epidemiologic studies to identify risk factors will provide key information for controlling dengue.

\section{Major zoonotic fungal diseases Dermatomycosis}

Dermatomycosis (ringworm) is a zoonotic disease distributed worldwide and caused by fungi of three genera (Microsporum, Trichophyton and Epidermophyton), belonging to the group referred to as dermatophytes. These three genera have the ability to be transmissible to animals as well as humans which signifies their intensity as animal and human health problem worldwide. Some species of dermatophytes will only infect humans or certain animals, whereas other can be spread from animals to animals. It appears from literature that Microsporium canis and M. gypseum affect mainly animals and $\quad M$. canis is the normal cause of ringworm in dogs and cats, and can cause infection in humans. Trichophyton mentagrophytes and $T$. verrucosum can cause rignworm in both humans and animals.

It is estimated that approximately $10 \%$ of human infections in urban and $80 \%$ in rural areas are of animal origin (Anon., 1956; Samad, 2008). Over $70 \%$ of cases are caused by M. canis, $20 \%$ by M. gypseum and $10 \%$ by $T$. mentagrophytes. The prevalence of clinical dermatomycosis has been reported $9.3 \%$ in cattle, $18.6 \%$ in goats and $25.2 \%$ in their contact humans, and higher prevalence of the disease was reported in young calves up to 6 months of age, laborer, animal attendant and house-wife, 30 to 50 years old people in monsoon season in Bangladesh (Nooruddin and Khaleque, 1986; Rashid et al., 1996a;b). It has been concluded that the higher prevalence of the disease in human population might be due to greater contact with animals. The isolation frequency of $T$. verrucosum $(72.0 \%)$ has been reported to be higher than $T$. mentagrophytes $(28.0 \%)$ in cattle and goats. However, the prevalence of anthopophilic molds ( $T$. violaceum, $P$. hortae) has been reported to be higher (53.4\%) than 46.6\% zoophilic molds (T. verrucosum, T. mentagrophytes) in humans (Rashid et al., 1996a,b).

Any infected pet is likely to contaminate furniture, bedding and carpets with resistant ringworm spores which may persist for up to 10 months. Humans can be infected and develop lesions following direct contact with clinically or asymptomatically affected animals, particularly cats. Indirect transmission via contaminated hair or scale in the environment or on fomites may also occur.

\section{Major zoonotic parasites}

Parasitic infections, caused by intestinal protozoa, helminths and arthropod parasites are among the most prevalent infections in humans and animals in developing countries (Crompton, 1999; Youn, 2009). Zoonotic parasites may be separated into four categories such as (a) Direct zoonotic parasites infecting humans directly from animals e.g. Entamoeba histolytica, Cryptosporidium parvum, Toxoplasma gondii, Sarcoptes scabiei, (b) Meta-zoonotic parasites infecting humans from invertebrate intermediate hosts e.g. Fasciola gigantica, Diphyllobothrium latum, Dipylidium caninum, Dirofilaria immitis, (c) Cyclo-zoonotic parasites having vertebrate intermediate hosts e.g. Taenia multiceps, Taenia saginata, Tania solium, Echinococcus granulosus, and (d) Sapro-zoonotic parasites meaning that parasites can infect humans from soil or water e.g. Ancylostoma caninum, Ascaris suum, Strongyloides stercoralis.

\section{Major zoonotic trematodes}

Among the trematode parasites of zoonotic importance, only Fasciola gigantica in ruminants (Samad, 2008; Kabir et al., 2010; Rahman and Samad, 2010) and Paragonimus westermani in cats (Samad and Rahman, 1998) have been reported from Bangladesh (Table 7). However, schistosome dermatitis in humans has been reported from Bangladesh (Islam and Awal, 1991). 


\section{Major zoonotic cestodes}

The prevalence of zoonotic parasites in pigs (Basak et al., 1988), dogs (Rahman, 1973; Karim et al., 1982; Rahman et al., 1988; Tarafder and Samad, 2010), cats (Samad and Rahman, 1998) and cattle (Rahman et al., 1988; Rahman and Samad, 2010) have been reported from Bangladesh and their zoonotic importance have been described (Table 7). The important zoonotic cestodes recorded from Bangladesh include Diphyllobothrium latum (13.3\%), Diphylidium caninum (16.67\%) and Echinococcus granulosus (9.17\%) in dogs (Table 7). The larval taenids parasites have also been reported in goats (Karim et al., 1982). Diphyllobothrium latum, a parasite with freshwater fish its intermediate host, occasionally infects people who frequently eat under-cooked or raw freshwater fish.

\section{Echinococcosis}

Echinococcosis (Hydatidosis or Hydatid disease) is an important zoonotic parasitic dangerous disease of humans and animals throughout the world. Echinococcus granulosus causes cystic disease, E. multilocularis causes alveolar disease and E. vogeli causes polycystic disease (Bob, 2011). Cystic echinococcosis (CE) is a condition of food animals and humans that arises from eating infective eggs of the cestode E. granulosus. Dogs are the primary definitive hosts for this parasite with livestock being as intermediate hosts and humans as aberrant intermediate hosts. Man acquires infection directly by contact with infected dogs or indirectly through contaminated food and water. The outcome of infection in livestock and humans is cyst development in the liver, lungs or other organ system (Islam, 1979; 1980a; 1981; 1982; Islam et al., 2003). The liver cyst may remain silent for 10 to 20 years or more until it becomes large enough to be palpable as an abdominal swelling to produce pressure effects or to produce systems due to leakage or rupture. If cyst ruptures, anaphylaxis and death may result.

Table 7. Prevalence of zoonotic parasites in man and animals in Bangladesh

\begin{tabular}{|c|c|c|c|c|}
\hline \multirow[t]{2}{*}{ S/NSpecies of parasites } & \multicolumn{4}{|c|}{ Recognized in hosts, No. + ve / No. tested (\%) } \\
\hline & $\begin{array}{l}\text { Pigs (41) } \\
(144,175)\end{array}$ & $\begin{array}{r}\text { Dogs }(92,105,134, \\
145,183)\end{array}$ & Cats $(164,174)$ & Cattle \\
\hline \multicolumn{5}{|l|}{ A. Trematodes } \\
\hline $\begin{array}{l}\text { (1) Paragonimus westermani } \\
\text { B. Cestodes }\end{array}$ & - & - & $02 / 22(9.09)$ & - \\
\hline (1) Diphyllobothrium latum & - & $08 / 60(13.3)$ & - & - \\
\hline (2) Diphylidium caninum & - & $10 / 60(16.67)$ & - & - \\
\hline (3) Echinococcus granulosus & - & $11 / 120(9.17)$ & - & - \\
\hline \multicolumn{5}{|l|}{ C. Nematodes } \\
\hline (1) Ancylostoma caninum & - & $60 / 60(100)$ & - & - \\
\hline (2) A. tubaeforme & - & - & $8 / 22(36.36)$ & - \\
\hline (3) Dirofilaria immitis & - & - & $2 / 22(9.09)$ & - \\
\hline (4) Gnathostoma spinigerum & - & $24 / 60(40.0)$ & - & - \\
\hline (5) Toxocara cati & - & - & $10 / 22(45.45)$ & - \\
\hline (6) Toxocara canis & - & $14 / 60(23.33)$ & - & - \\
\hline (7) Trichuris vulpis & - & $8 / 60(13.8)$ & - & - \\
\hline \multicolumn{5}{|l|}{ D. Protozoa } \\
\hline (1) Cryptosporidium parvum & - & - & - & - \\
\hline (2) Entaemobea histolytica & $20 / 120(17.24)$ & - & - & - \\
\hline (3) Balantidium coli & $70 / 120(60.34)$ & - & - & $11 / 87(12.64)$ \\
\hline (4) Giardia lamblia & - & - & - & - \\
\hline (5) Toxoplasma gondii & - & - & $2 / 22(9.09)$ & $66 / 399916.54)$ \\
\hline
\end{tabular}

The results on the prevalence of cystic echinococcosis in humans and animals are analyzed from inland published reports (Table 8). These findings demonstrate the necessity for increased monitoring and control of cystic echinococcosis. Prevention of cystic echinococcosis could be done by prophylactic treatment of pet dogs with praziquantel or albendazole and prevention of feeding offal to dogs. 


\section{Major zoonotic nematodes}

The prevalence of nematode parasites in humans and animals have been reported from Bangladesh (Samad, 2000b), but dogs and cats are the main reservoirs of the zoonotic nematodes for humans (Table 7).

Table 8. Prevalence of cystic echinococcosis in man and animals in Bangladesh

\begin{tabular}{|cllllll|}
\hline S/N Diseases & Host & $\begin{array}{l}\text { No. of } \\
\text { population } \\
\text { tested }\end{array}$ & Types & Test used & Positives & $\begin{array}{l}\text { Reference } \\
\text { No. }\end{array}$ \\
\hline Hydatid disease & Buffaloes & 2704 & Carcass & Field test & $604(22.34)$ & $85,87,94$ \\
& Cattle & 2608 & Carcass & Field test & $610(23.39)$ & 100,114 \\
& Sheep & 763 & Carcass & Field test & $331(43.43)$ & 90,100 \\
& Goats & 13798 & Carcass & Field test & $1188(08.61)$ & $91,93,100$ \\
\hline
\end{tabular}

Major zoonotic protozoa

There are about 65,000 species of protozoan parasites in the world. The most common zoonotic protozoan diseases are amoebiasis, Giardiasis, Balantidiasis, Cryptosporidiosis and Toxoplasmosis (Hoque et al., 1994; Haque et al., 2009).

\section{Amoebiasis}

Amoebiasis is a parasitic disease caused by the protozoan Entamoeba histolytica. This disease is prevalent worldwide but is most prevalent and severe in tropical countries where prevalence rate may exceed $40 \%$ under conditions of crowding, poor sanitation and poor nutrition. Amoebiasis is the third leading cause of death from parasitic diseases worldwide, with its greatest impact on the people of developing countries. WHO estimates that approximately 50 million people worldwide suffer from invasive amoebic infection annually, resulting in 40,000 to 100,000 deaths annually (Haque, 2007). The occurrence of this protozoan has been reported from 0 to $3 \%$ in the feces of apparently healthy Rhesus monkeys and up to $30 \%$ in other non-human primate (Samad, 2008). The prevalence of $E$. histolytica infection has been reported in 5\% and E. dispar in 13\% of asymptomatic 2 to 5 yearold children from an urban slum of Dhaka, Bangladesh (Haque et al., 1999).

Transmission is usually by ingestion of infective cysts which contaminated with food and water. The cysts remain viable for 12 days in moist environment and 30 days in water. It is characterized in humans by mild to moderate colitis, recurrent diarrhea, stools streaked with blood and mucus. Hepatic amoebiasis is characterized by fever, hepatomegaly, pain and localized tenderness. This disease can be prevented by strict sanitation and personal hygiene, protective clothing and gloves. In addition, fecal contamination of feed and water should be prevented, and fecal screening of NHP and adequate cooking to destroy the cysts need to be done.

\section{Giardiasis}

Giardiasis is a recognized zoonotic parasitic disease caused by Giardia intestinalis (G. lamblia, G. duodenalis). It infects the intestinal tract of many animal species including humans which is the most prevalent parasitic cause of diarrhea in both the developed and developing world. Giardia species have long been considered zoonotic because morphologically similar organisms infect humans and a variety of mammals and birds. This protozoan has both a cyst (infective) and trophozoite form. Motile trophozoite stages occur in the intestines and environmentally resistant cysts are passed in the feces of infected animals, which are immediately infective if ingested by other susceptible hosts. Only the cyst form is infectious by the oral route whereas trophozoites are destroyed by gastric acidity. Humans are the reservoir for this protozoa but dogs, cats and bears have been implicated as a zoonotic source of infection. This disease has also been reported in calves and psittacines birds especially cockatiels and budgerigars. Most infections are sporadic resulting from cysts transmitted as a result of fecal contamination of water and food, by person-to-person contact or by anal-oral sexual contact.

The ingested cysts are converted to trophozoites in the duodenum and jejunum, which cause epithelial damage, atrophy of villi and hypertrophic crypts. Most infections are asymptomatic in humans but some cases may develop acute or chronic diarrhea, mild to severe, with bulky, greasy, frothy, malodorous stools, free of pus and blood (Bob, 2011). The most common signs of giardiasis in dogs are diarrhea which can be acute, chronic or intermittent. 
Zoonotic diseases in Bangladesh

Table 9. Prevalence of major zoonotic protozoan diseases in Bangladesh

\begin{tabular}{|c|c|c|c|c|c|c|c|}
\hline \multicolumn{2}{|c|}{ S/N Diseases } & Host & $\begin{array}{l}\text { No. of } \\
\text { population } \\
\text { tested }\end{array}$ & Types & Test used & $\begin{array}{l}\text { Positives } \\
\text { No. (\%) }\end{array}$ & $\begin{array}{l}\text { Reference } \\
\text { No. }\end{array}$ \\
\hline \multirow[t]{2}{*}{ (1) } & Amoebiasis & Children & 289 & Diarrheic & Fecal test & $231(80.00)$ & 72 \\
\hline & & & 680 & A. healthy & Fecal test & $032(4.71)^{+}$ & 73 \\
\hline \multirow[t]{2}{*}{ (2) } & Balantidiasis & Cattle & 1108 & Diarrheic & Fecal test & $19(1.71)$ & 8,144 \\
\hline & & Buffaloes & 000 & Diarrheic & Fecal test & $83(0.00)$ & 101 \\
\hline \multirow[t]{5}{*}{ (3) } & Cryptosporidiasis & Calves & 208 & Diarrheic & Fecal test & $29(14.00)$ & 128 \\
\hline & & Calves & 202 & Non-diarrheic & Fecal test & $02(01.00)$ & 128 \\
\hline & & Humans* & 165 & Diarrheic & Fecal test & $14(08.48)$ & 128 \\
\hline & & Humans & 155 & Non-diarrheic & Fecal test & $000(0.00)$ & 128 \\
\hline & & Humans & 1585 & Diarrheic & Fecal test & $060(3.79)$ & $76,108,128$ \\
\hline (4) & Giardiasis & Humans & 2534 & A. healthy & Fecal test & $322(12.71)$ & $69,74,75$ \\
\hline (5) & Leishmaniasis & Humans & 131480 & A. healthy & Rapid test & $2986(2.27)$ & $1,42,116$ \\
\hline \multirow[t]{8}{*}{ (6) } & Toxoplasmosis & Cattle & 399 & A. healthy & IHT, LAT & $066(16.54)$ & 153,159 \\
\hline & & Sheep & 117 & A. healthy & LAT & $033(28.21)$ & 159,163 \\
\hline & & Goat & 415 & A. healthy & LAT & 049 (11.81) & $158,159,163$ \\
\hline & & Goat & 015 & $\mathrm{R}$ disorders & LAT & 004 (26.67) & 159 \\
\hline & & Pregnant & 447 & A. healthy & ELISA & $261(58.39)$ & 161,166 \\
\hline & & women & 447 & R. disorders & ELISA & $186(41.61)$ & \\
\hline & & & 186 & A. healthy & ELISA & $075(40.32)$ & 163,166 \\
\hline & & Cats & 24 & A. healthy & LAT & $008(33.33)$ & 163 \\
\hline
\end{tabular}

*Humans- animal handlers and family members $\quad{ }^{+}$E. histolytica 32 (4.71\%) and E. dispar 86 (12.6\%)

The age specific prevalence of $G$. lamblia has been reported in two Bangladeshi villages and malnourished children in Dhaka city hospitals. Infection has shown to be acquired early $(<1$ year) and in $16 \%$ of infected children persisted for longer than three months. Prevalence has recorded higher in 5 to 10-year old village children (21\%) and one to five-year-old malnourished children (51\%) in Bangladesh (Gilman et al., 1985).

Zoonotic giardiasis may be controlled by routine screening of feces of dogs and non-human primates. Hygiene and protective clothing when handling animals are needed. Prevention requires safe water supplies, sanitary disposal of human feces, adequate cooking of foods to destroy cysts, protection of foods from fly contamination, washing hands after defecation and before preparing or eating foods.

\section{Balantidiosis}

Blandidiasis is an infectious feco-oral transmitted zoonotic disease caused by a single-celled protozoan called Blantidium coli that infect the digestive system. This disease is found worldwide with more prevalence in the tropics. This protozoa infect a wide variety of mammals and especially common in monkeys and pigs which generally regarded as the main reservoir for human infection. Prevalence in pigs ranges from 20 to $100 \%$ and human balantidiosis usually exhibits an increased prevalence in communities that like in close association with pigs. For example, in Papua New Guinea, where pigs are the principal domestic animals, the prevalence among swine herders and slaughter house workers has been reported to be as high as $28 \%$ (Schuster and Ramirez-Avila, 2008). Human-to-human transmission has also been documented and this method of transmission is likely to occur in environment with crowding and poor personal hygiene. It is transmitted primary by eating food or drinking water that has been contaminated by human or animal feces containing B. coli cysts. Balantidiosis associated with diarrhea in cattle (Alam et al., 1979) and water buffaloes (Islam et al., 2000) and pigs (Basak et al., 1988) has been reported from Bangladesh (Table $7 \&$ 9) but its zoonotic significance has not been evaluated under local conditions.

\section{Cryptosporidiosis}

Cryptosporidiosis is a zoonotic disease affecting mainly the gastro-intestinal system of man, animals and birds, caused by Cryptosporidium parvum. This causal agent is a coccidian, oocyst-forming apicomplexan protozoa which complete their life cycle both in humans and animals, through zoonotic and anthroponotic transmission.

The distribution of this parasite may be associated to environmental (e.g. geographic and temporal clusters) and host determinants of the infection (e.g. age, immunological status, travels, community behaviors). Cryptosporidium species are transmitted via the fecal-oral route by environmentally resistant cysts that are shed in the feces, contaminating soil and water, and, thus, providing multiple routes into the food chain. 


\section{A. Samad}

Infection with this parasite is usually asymptomatic or mild and self limiting diarrhea in immune-competent hosts but can be severe, can be life-threatening and chronic in immuno-compromised individual such as patients with AIDS or in severely malnourished children. The infection may be transmitted by direct person-to-person spread, contact with infected animals or by ingestion of contaminated food or water.

In humans, the most commonly detected species are the anthroponotic C. hominis and the zoonotic C. parvum (cattle). The $\operatorname{dog}$ is the natural host of $C$. canis and cats for $C$. felis have also been demonstrated in infected humans suffering diarrhea. Young children and immuno-compromised individuals are at greatest risk.

Cryptosporidiosis has been recognized as a significant cause of diarrheal disease in young children of Bangladesh (Shahid et al., 1985; Khan et al., 2004). In addition, the occurrence of this infection in calves and their handlers (Table 9) has also been reported in Bangladesh (Rahman et al., 1984). Retrospective case-control studies on this disease revealed 1.4 to $3.5 \%$ diarrheic patients had cryptosporidium infection as one of the major enteropathogens significantly associated with diarrhea in young children in Bangladesh (Khan et al., 2004). Cryptosporidiosis has been found in people, neonatal farm animals, pets living in the same environment, suggesting the potential for zoonotic transfer between species exists. Symptoms in humans include watery diarrhea, fever, abdominal cramps, nausea and vomiting but infection in immuno-suppressed individuals like very young, the elderly or those with HIV/AIDS may be life threatening. Personal hygiene including careful hand-washing by those in contact with any animals with scours is needed for prevention.

\section{Leishmaniasis}

Leishmaniasis is caused by more than 20 different leishmanial species of flagellated protozoan parasites reported from at least 80 countries of the world including Bangladesh. WHO estimates the worldwide prevalence to be approximately 12 million cases, with annual mortality of about 60,000 and the population at risk is about 350 million. Several forms of leishmaniasis exist which include cutaneous (CL, oriental sore, Delhi boil), mucocutaneous and visceral (VL, also called 'kala-azar') which after treatment, is often followed by a dermal manifestation known as 'post-kala-azar' dermal leishmaniasis (PKDL). The 'kala-azar', the most lethal form of the disease is caused by Leishmania donovani, which is of major public health importance in Bangladesh, India and Nepal, affecting the poorest population groups, primarily in rural areas. More than $60 \%$ of the world's VL cases are reported from these three countries and an estimated 150 million people are at risk of VL in 109 districts. The region reports 40,000 or more cases per year and results in an estimated loss of 400,000 disabilityadjusted life years (DALYS) annually (Mondal et al., 2009).

The VL ('kala-azar') was first described in 1824, in Jessore district in Bangladesh (Sengupta, 1944) and endemic peaks were recorded in Bengal in the 1820s, 1860s and 1940s. Then this malady was control during the intensive vector control for malaria in the 1950 to 1960s. It again shows an increasing trend in incidence since 1995 (Bern and Chowdhury, 2006). Recently, sporadic outbreaks of leishmaniasis have been recorded and even sporadic outbreaks are continuing in humans in the different districts of Bangladesh including Mymensingh, Panchagarh and others (Rahman and Islam, 1983; Talukder et al., 2003; Rahman et al., 2009).

Transmission of leishmaniasis is most often zoonotic; the Leishmania are transmitted from a animal reservoir like wild animals, small rodents and dogs, by the bite of the female phlebotomine sand fly. Person-to-person, congenital and blood-borne transmission is also possible. L. donovani produces visceral lesions in dogs, with enlarged lymph nodes, liver and spleen, and in humans it is characterized by intermittent irregular fever occurs with sweats, enlarged spleen, weight loss and anemia leading to ascites, edema, diarrhea and secondary infections (Bob, 2011). The expansion of leishmaniasis and the alarming rise in the number of cases is related to environmental changes such as deforestation, building of dams, new irrigation schemes and poverty status of these people. Vector control by use of insecticides in house and buildings, eliminate rubbish heaps which are breeding areas for vector sand flies, avoid sand fly bites by using insect repellents and insecticides-treated nets and reservoir control could be effective in preventing kala-azar'(Elias et al., 1989).

\section{Toxoplasmosis}

Toxoplasmosis is an important protozoan disease of man and animals, caused by the protozoan parasite Toxoplasma gondii. An estimated 500 million humans have been infected with the protozoa (Bob, 2011). Analysis of global sero-survey reports revealed that about $32.9 \%$ cats, $38.5 \%$ man, $29.0 \%$ sheep, $24.2 \%$ goats, $18.6 \%$ cattle, $20.7 \%$ swine, $16.9 \%$ horse, $39.3 \%$ dogs, $17.7 \%$ buffaloes and $18.7 \%$ camels had $T$. gondii antibodies (Samad and Begum, 1990). The fecal examination of 4232 cats from 22 reports of 10 countries showed that about $2.7 \%$ of the cat population would have been shedding $T$. gondii oocysts at any one time 
(Samad and Begum, 1994). Sero-surveillance studies on toxoplasmosis on man and animals showed 16 to $37 \%$ cattle, 17.65 to $53.6 \%$ sheep, 12.09 to $36.4 \%$ goats and $15.89 \%$ women had $T$. gondii antibodies in Bangladesh (Samad et al., 1982; Samad et al., 1993a,b,c).

In addition, reproductive disorders in goats (Samad, 1992; Bari et al., 1993) and women (Samad et al., 1993c; Samad et al., 1998) associated with toxoplasmosis have been reported from Bangladesh. Economic losses due to toxoplasmosis are mainly associated with abortion and congenital infection in man and animals.

Cats are the definitive hosts for $T$. gondii, which they acquire when they eat infected intermediate hosts (rodents and many other mammals) or ingest oocysts excreted in the stools of other infected cats. Infected cats are important in the epidemiology and public health importance of toxoplasmosis because they excrete and widely disperse the environmentally resistant oocysts. Presumably all serologically positive cats have shed toxoplasma oocysts and could re-shed oocysts during re-infection or reactivation by induction of hypercorticism or superinfection with other feline microorganisms.

Epidemiologic evidence suggests that the human become infected by ingesting food and water contaminated with oocysts shed in the feces of infected cats (ingesting sporulated oocysts from cat), or consumption of undercooked meat from infected animals containing cysts, or drinking of raw goat's milk containing tachyzoites and transplacentally. Vast majority of the human infections are either asymptomatic or result in only mild clinical disease but the major concern is congenitally acquired toxoplasmosis. Reproductive wastages due to toxoplasmosis can only occur when a previously unexposed (non-immune) women acquires toxoplasmosis during pregnancy. In this situation, there is approximately a $40 \%$ chance that the fetus will acquire the infection, and is around $10 \%$ of these cases, severe neurological or ocular disease is present at birth. However, clinically evident toxoplasmosis has been reported in about $11.7 \%$ with AIDS, $45.7 \%$ with blood cancer and $8.5 \%$ with transplant patients. The methods of diagnosis and control of toxoplasmosis in domestic animals and humans have been described (Samad and Begum, 1994).

\section{Major zoonotic arthropods}

Sarcoptes scabiei, causing scabies, is the most important zoonotic arthropod in Bangladesh (Huq et al., 1985) and around the world (Samad, 2008).

\section{Zoonotic diseases and poverty in developing country Bangladesh}

Zoonotic diseases are common throughout the world and constitute an important threat to human health in developing countries like Bangladesh. It appears from the literatures that meat (Rahman et al., 1997), milk (Samad, 2008), eggs (Borhanuddin et al., 1986), water (Rahman et al., 1978b) and other foods contained high numbers of coliforms, staphylococci, salmonella pathogens. The poor people in particular may tend to be at risk from zoonotic diseases for a number of reasons: (a) The poor often live in close contact with their livestock and are thus at increased risk of contracting zoonotic diseases, (b) Access to education on the prevention of zoonotic diseases in often unavailable to the poor livestock keepers, (c) Poor consumers may be at greater risk from foodborne diseases, (d) Informal sales of animal products make the maintenance of hygienic conditions and the control of food quality very difficult, (e) In poor and remote areas, hygienic abattoirs and facilities for meat inspection are often limited. Contracting a zoonotic disease may have serious consequences for a poor person who will probably have poor access to healthcare and can ill afford to have his/her ability to work impaired by sickness.

\section{REFERENCES}

1. Ahluwalia IB, Bern C, Costa C and Akter T, Chowdhury R, Ali M et al. (2003). Visceral leishmaniasis: consequences of a neglected disease in a Bangladeshi community. American Journal of Tropical Medicine and Hygiene 69 : 624-628.

2. Ahmed B, Sultana Y, Fatema DSM, Ara K, Begum N, Mostanzid SM and Jubayer S (2010). Anthrax: An emerging zoonotic disease in Bangladesh. Bangladesh Journal of Medicial Microbiology 4: 46-50.

3. Ahmed JU, Alam MGS, Rahman MM and Hossain M (1992). Seroprevalence of brucellosis in indigenous zebu cows of Bangladesh. Bangladesh Journal of Microbiology $9:$ 17-21.

4. Ahmed MU, Taniguchi K, Kobayashi N, Urasawa T, Wakasugi F, Islam AIM, Shaikh AH and Urasawa S (1989). Characterization by enzyme linked immunosorbent assay using subgroup and serogroup and serotype specific monoclonal antibodies of human rotavirus obtained from diarrheic patients in Bangladesh. Journal of Clinical Microbiology 72: 1678-1681. 
5. Ahmed MU, Taniguchi K, Kobayashi N, Urasawa T, Wakasugi F, Islam AIM, Shaikh AH and Urasawa S (1991). Analysis of human rotavirus strains prevailing in Bangladesh in relation to nation-wide floods brought by the 1988 monsoon. Journal of Clinical Microbiology 29: 2273-2279.

6. Ahmed MU, Alam MM, Chowdhury NS, Haque MM, Shaid N, Kobayashi N, Taniguchi K, Urasawa T and Urasawa S (1999). Analysis of human rotavirus G serotype in Bangladesh by Enzyme linked immunosorbent assay and polymerase chain reaction. J Diarrhoeal Dis Res. 17 : 22-27.

7. Ahmed FU, Mahmood CB, Sharma JD, Hoque SM, Zaman R and Hasan MH (2001). Dengue and dengue haemorrhagic fever in children during the 2000 outbreak in Chittagong, Bangladesh. Dengue Bulletin 25: 33-39.

8. Alam MGS, Rahman A and Sen MM (1979). Blantidiasis in cattle. Bangladesh Veterinary Journal 13: 39-42.

9. Alam MM, Huque AKMF, Nigar S, Haque M, Chowdhury NS and Ahmed MU (1994). Rotavirus infection in children and calves in association with acute gastro-enteritis. Bangladesh Veterinary Journal 28: 35-40.

10. Alam MM, Ahmed NU, Chowdhury NS and Urasawa S (1999). Detection of group and sub-group specific antigens of bovine rotaviruses in Bangladesh. Journal of Diarrhoeal Disease Research 17: 81-84.

11. Ali MW, Majumder MJU, Haq F, Latif MA, Bari IF and Alam S (1982). Studies on the presence of rabies virus among stray dogs in Dhaka city. Bangladesh Medical Research Council Bulletin 8: 59-62.

12. Ali MY, Rahman MT, Islam MA, Choudhury KA and Rahman MA (1998). Characterization of Escherichia coli isolated of human and animal origin. Progressive Agriculture 9: 221-224.

13. Amim MMM, Hussain AMZ, Murshed M, Chowdury IA and Banu D (1999). Sero-diagnosis of dengue infections by haemagglutination inhibition (HI) in suspected cases in Chittagong, Bangladesh. Dengue Bulletin 23: 34-38.

14. Amim MMM, Hussain AMZ, Nahar K, Chowdury IA, Murshed M and Chowdhury SA (2000). Serodiagnosis of dengue infections in four metropolitan cities of Bangladesh. Dengue Bulletin 24: 34-41.

15. Anon. (1956). Animal reservoir of ringworm infection in Britain. Veterinary Record 68: 357.

16. Anon. (2004). Nipah encephalitis outbreak over wide area of Western Bangladesh. Health and Science Bulletin 2: 7-11.

17. Anon. (2005). Nipah virus outbreak from date palm juice. Health and Science Bulletin 3: 1-5.

18. Anon (2007). Person-to-person transmission of Nipah infection in Bangladesh. Health and Science Bulletin 5: $1-6$.

19. Anon. (2008a). First confirmed human infection with avian influenza A (H5N1) virus in Bangladesh. Health and Science Bulletin 6: 1-6.

20. Anon. (2008b). Outbreak of Nipah virus in Rajbari and Manikgonj. Health and Science Bulletin 6: 12-13.

21. Anon. (2008c). Bangladesh reports its first human H5N1 case. Center for Infectious Disease Research and Policy, Academic Health Center, USA.

22. Anon. (2008d). Role of ICDDR'B in addressing avian influenza in Bangladesh. www.icddrb.org/what-wedo/publications/cat_view/52-publication/10042-icddrb-peridicals/10078.glimpse/10297-vol-30-no-12008/11103-role-of-icddrb.

23. Anon. (2009). ICDDR'B. Cutaneous anthrax outbreaks in two districts of north-western Bangladesh, August-October, 2009. Health Science Bulletin 7: 1-9.

24. Anon. (2010a). Nipah outbreak in Faridpur district Bangladesh, 2010. Health and Science Bulletin 8: 6-11.

25. Anon. (2010b). Anthrax outbreaks in Bangladesh: an update. Health and Science Bulletin 8: 1-7.

26. Anon. (2010c). Anthrax update. Institute of Epidemiology, Disease control and research, Dhaka. http://www.iedcr/Default.aspx?Tabid= 135 .

27. Anon. (2010d). Anthrax in Lalmonirhat. http://www.bangladeshnews.com.bd/2010/09/08/anthrax-inlalmonirhat/.

28. Anon. (2010e). Nationwide tuberculosis prevalence survey in Bangladesh, 2007-2009. Health and Science Bulletin 8: 13-17.

29. Anon. (2011a). Second human case of H5N1 'bird flu' in 2011 identified in Dhaka, Bangladesh. http://remixxworld.blogspot.com/2011.

30. Anon. (2011b). Bangladesh-male, 3, H5N1 confirmed (third case in Bangladesh, second case in 2011). http://www.flutrackers.com/ forum/showthread.php?t=164386. 
31. Anon. (2011c). Recurrent animal and human anthrax outbreaks in Bangladesh: Improved vaccination strategies needed. ICDDR'B. Health and Science Bulletin 9: 8-14.

32. Anon. (2011d). Zoonosis. http://en.wikipendia.org/wiki/zoonosis.

33. Anon. (2011e). The nature of emerging zoonotic diseases: ecology, prediction and prevention. http://www.thefree-tib-rary.com/The+ nature+of+emerging+zoonotic+diseases $\% 3 \mathrm{a}+$ ecology.

34. Anon. (2011f). Zoonotic diseases of smallstock. http://www.smallstock.infor/infor/health/zoonoses.htm

35. Anon. (2011g). Leptospirosis during dengue outbreak, Bangladesh. http://www.the freelibray.com/ leptospirosis+during + dwbgue + outbreak.

36. Anon. (2012). Cutaneous anthrax cases in 2012 according to reporting. www.flutrackers.com/forum/ showthread.php?t=188423.

37. Aziz MA, Gorham JR and Gregg MB (1967). Dhaka fever- An outbreak of dengue. Pak J Med Res 6: 83-92.

38. Aziz MM, Hasan KN, Hasanat MA, Siddiqi MA, Salimullah M, Chowdhury AK, Ahmed M, Alam MN and Hassan MS (2002). Predominance of the DEN-3 genotype during the recent dengue outbreak in Bangladesh. Southeast Asian Journal of Tropical Medicine and Public Health 33: 42-48.

39. Baqi MA and Khyam SU (2011). Overview of recent outbreak of Avian influenza in Bangladesh. Avianinfluenza-Bangladesh.pdf

40. Bari ASM, Yeasmin F and Alam MGS (1993). Pathology of naturally occurring Toxoplasma abortion and neonatal mortality in Black Bengal goat. Small Runinant Research 10: 349-355.

41. Basak SC, Mondal MMH, Baki MA and Ahmed S (1988). Prevalence of gastro-intestinal parasites of pigs in Bangladesh. Bangladesh Veterinary Journal 22: 9-12.

42. Bern C, Hightower AW, Chowdhury R, Ali M, Amann J, Wagatsuma Y, Haque R, Kurkjian K, Vaz LE, Begum M, Akter T, Cetre-sossah CB, Ahluwalia IB, Dotson E, Secor WE, Breiman RF and Maguire JH (2005). Risk factors for kala-azar in Bangladesh. Emerging Infectious Diseases 11: 4-7

43. Bern $\mathrm{C}$ and Chowdhury R (2006). The epidemiology of visceral leishmaniasis in Bangladesh: prospects for improved control. Indian Journal of Medical Research 123: 275-288.

44. Biswas RK, Samad MA and Khan AM (1986). Prevalence of Japanese encephalitis antibodies in animals of Bangladesh. Indian Veterinary Medical Journal 10: 16-19.

45. Biswas HR, Hoque MM, Samad MA and Rahman A (1996). Prevalence of inapparent rabies infection in street dogs. Bangladesh Veterinarian 13: 29-31.

46. Biswas PK, Christensen JP, Ahmed SSU, Barua H, Das A, Rahman et al. (2008). Avian influenza outbreaks in chickens, Bangladesh. Emerging Infectious Diseases 14: 1909-1912.

47. Biswas PK, Christensen JP, Ahmed SSU, Das A, Rahman MH, Barua H, Giasuddin M, Hannan ASMA, Habib MA and Debnath NC (2009). Risk for infection of highly pathogenic avian influenza virus (H5N1) in backyard chicken in Bangladesh. Emerging Infectious Diseases 15: 1931-1936.

48. Blum LS, Khan R, Nahar N and Breiman RF (2009). In-depth assessment of an outbreak of Nipah virus infection with person-to-person transmission in Bangladesh: implications for prevention and control. American Journal of Tropical Medicine and Hygiene 80: 96-102.

49. Bob (2011). Dr. Bob's all creatures site. WWW.Petdoc.ws, Zooonotic Diseases. file:///F:/zoonotic_ diseases1.htm, pp 1-169.

50. Borhanuddin M, Ali R and Rahman MM (1986). Microbial contamination level of market shell eggs. Bangladesh Veterinary Journal 20: 95-99.

51. Chakraborty A, Khan SU, Hasnat MA, Parveen S, Islam MS, Mikolon A, Chakraborty RK, Ahmed B, Ara K, Haider N, Zaki SR, Hoffmaster AR, Rahman M, Luby SP and Hossain MJ (2012). Anthrax outbreaks in Bangladesh, 2009-2010. American Journal of Tropical Medicine and Hygine 86: 703-710.

52. Chowdhury AQ, Miah RA, Akhtar N and Jubayer SM (2004). Sero-prevalence of dengue infections amongst the children. Mymensingh Medical Journal 13: 59-62.

53. Cook N, Bridger J, Kendall K, Gomara MI, El-Attar L and Gray J (2004). The zoonotic potential of rotavirus. Journal of Infection 48: 289-302.

54. Cosivi O, Grange JM, Daborn CJ, Raviglione MC, Fujikura T, Cousins D, Robinson RA, Huchzermeyer HFAK, Kantor Ide and Meslin FX (1998). Zoonotic tuberculosis due to Mycobacterium bovis in developing countries. Emerging Infectious Diseases 4: 59 -70. 
55. Crompton DWT (1999). Estimates of current numbers of human helminth (worm) infections. Journal of Parasitology 85: 379-403.

56. Cutler SJ, Fooks AR and van der Poel WHM (2010). Public health threat of new, reemerging and neglected zoonoses in the industrial world. Emerging Infectious Diseases 16: 1-7.

57. Daszak P, Epstein JH, Kilpatrick AM, Aguirre AA, Karesh WB and Cunningham AA (2007). Collaborative research approaches to the role of wildlife in zoonotic disease emergence. Current Tropical Medicine and Immunology 315: 463-475.

58. Datta S, Niwa H and Itoh K (2003). Prevalence of pathogenic genes of Campylobacter jejuni by PCR in strains isolated from humans, poultry meat and broiler and bovine faeces. Journal of Medical Micriobiology 52: $345-248$

59. Debnath NC, Huq MI, Rahman A, Pandit KK and Haque AFMH (1986). Isolation of Campylobacter jejuni from domestic ruminants and poultry. Bangladesh Veterinary Journal 20: 41- 45.

60. Dey BK, Ahmed MS and Ahmed MU (2007). Rotaviral diarrhea in kids of Black Bengal goats in Mymensingh. Bangladesh Journal of Veterinary Medicine 5: 59-62.

61. Dey SK, Hayakawa Y, Rahman M, Islam R, Mizuguchi M, Okitsu S and Ushijima H (2009). G2 strain of rotavirus among infants and children, Bangladesh. Emerging Infectious Diseases 15: 1-5.

62. Dixon TC, Meselson M, Guillemin J and Hanna PC (1999). Anthrax. New England Journal of Medicine. 341: 815-826.

63. Elias M, Rahman AJ and Khan NI (1989). Visceral leishmaniasis and its control in Bangladesh. Bulletin of World Health Organization 67: 43-49.

64. Erlanger TE, Weiss S J, Utzinger J and Wiedenmayer K (2009). Past, present and future of Japanese encephalitis. Emerging Infectious Diseases. 15: 00-00.

65. Ershaduzzam M, Rahman MB, Rahman MM, Miah MF and Rahman MF (1992). Rotavirus infection in calves of semi-intensive and semi-extensive farming areas in Bangladesh. Bangladesh Journal of Microbiology 9: 11-15.

66. Fasanella A, Garofolo G, Hossain MJ, Shamsuddin M, Blackburn JK and Hugh-Jones M (2012). Bangladesh anthrax outbreaks are probably caused by contaminated livestock feed. Epidemiology and Infection CJO 2012 doi:10.1017/S0950268812001227.

67. Fun BN, Unicomb L, Rahman Z, Banu NN, Podder G, Clemens J, Van Loon FP, Rao MR, Malek A and Tzipori S (1991). Rotavirus-associated diarrhea in rural Bangladesh: two-year study of incidence and serotype distribution. Journal of Clinical Microbiology 29: 1359-1363.

68. Gaidamovich SY, Siddiqi SM, Haq F, Klisenko GA, Melnikova EE and Obukhova VR (1980). Serological evidence of dengue fever in the Bangladesh Republic. Acta Virology 24: 153.

69. Gilman RH, Brown KH, Visvesvara GS, Mondal G, Greenberg B, Sack RB, Brandt F and Khan MU (1985). Epidemiology and serology of Giardia lamblia in a developing country: Bangladesh. Transaction of Royal Society of Tropical Medicine and Hygiene 79: 469-473.

70. Gurley ES, Montgomery JM, Hossain MJ, Bell M, Azad AK, Islam MR et al. (2007). Person-to-person transmission of Nipah virus in a Bangladeshi community. Emerging Infectious Diseases 13: 10-15.

71. Haq JA and Rahman KM (1991). Campylobacter jejuni as a cause of acute diarrhea in children: a study at an urban hospital in Bangladesh. Journal of Tropical Medicine and Hygiene 95: 218-220.

72. Haque R, Faruque AS, Hahn P, Lyerly DM and Petri WA (1997). Entamoeba histolytica and Entamoeba dispar infection in children in Bangladesh. Journal of Infectious Diseases 175: 734-736.

73. Haque R, Ali IM and Petri WA Jr (1999). Prevalence and immune response to Entamoeba histolytica infection in preschool children in Bangladesh. American Journal of Tropical Medicine and Hygiene 60: 1031-1034.

74. Haque R, Roy S, Kabir M, Stroup SE, Mondal N and Hoqupt ER (2005). Giardia assemblage A infection and diarrhea in Bangladesh. Journal of Infectious Diseases 192: 2171-2173.

75. Haque R (2007). Human intestinal parasites. Journal of Health Population and Nutrition 25: 387-391.

76. Haque R, Mondal D, Karim A, Molla IH, Faruque AS, Ahmed N, Kirkpatrick BD, Houpt E, Snider C and Petri WA (2009). Prospective case-control study of the association between common enteric protozoan parasites and diarrhea in Bangladesh. Clin Infect Dis http://www.rf-pcr.com/showabstract.php?pmid= 19323634. 
77. Harcourt BH, Lowe L, Tamin A, Liu X, Bankamp B, Bowden N et al. (2005). Genetic characterization of Nipah virus, Bangladesh, 2004. Emerging Infectious Diseases 11: 1594-1597.

78. Herriman R (2012). More than two dozen infected with anthrax in Bangladesh after eating infected cow. Outbreaknews.com/2012/05/29.

79. Hoque SS, Faruque AS, Mahalanabis D and Hasnat A (1994). Infectious agents causing acute watery diarrhea in infants and young children in Bangladesh and their public health implications. Journal of Tropical Pediatrics. 40: 351-354.

80. Hossain MA, Khatun M, Arjumand F, Nisalak A and Breiman RF (2003). Serologic evidence of dengue infection before onset of epidemic, Bangladesh. Emerging Infectious Diseases 9: 1411-1414.

81. Hosain MJ, Gurley ES, Montgomery JM, Beli M, Carrol DS, Hsu VP et al. (2008). Clinical prevalence of Nipah virus infection in Bangladesh. Clinical Infectious Diseases 46: 977-984.

82. Hossain MJ, Gurley ES, Montgomery S, Peterson L, Sejvar J, Fischer M, Panella A, Powers AM, Nahar N, Uddin AKMR, Rahman ME, Ekram ARMS, Luby SP and Breiman RF (2010). Hospital-based surveillance for Japanese encephalitis at four sites in Bangladesh 2003-2005. American Journal of Tropical Medicine and Hygiene 82: 344-349.

83. Hsu VP, Hossain MJ, Parashar UD, Ali MM, Ksiazek TG, Kuzmin I et al. (2004). Nipah virus emergence, reemergence, Bangladesh. Emerging Infectious Diseases 10: 2062-2067.

84. Huq F and Moyenuddin M (1984). Isolation and identification of Mycobacterium from patients with pulmonary tuberculosis, Bangladesh. Medical Research Communication Bulletin 10: 39-44.

85. Huq MM (1968). Hydatidosis in buffalo. Pakistan Journal of Veterinary Science 2: 162-164.

86. Huq MM, Shaikh, Karim MJ and Khan MM (1985). Scabies in man and dogs. Bangladesh Veterinary Journal 19: 63-65.

87. Huq AKMM, Hossain MI and Mosleuddin (1997). Pathological investigation of liver of the slaughter buffaloes in Dhaka city corporation. Bangladesh Veterinary Journal 31: 61-69.

88. Hussain SM, Hossain MJ, Gurley E and Lubery L (2004). Japanese encephalitis: Bangladesh perspective: A Review. Journal of Teachers Association RMC 17: http://academic.research.microsoft.com/ paper /13659242.

89. Irin (2011). Bangladesh: Bird flu outbreaks up sharply in 2011. Crowded backyard poultry markets in Bangladesh facilitate H5N1 outbreaks. www.irinnews.org/Report/92141.

90. Islam AWMS (1979). Hydatid disease in sheep of Mymensingh district, Bangladesh. Journal of Parasitology 65: 37.

91. Islam AWMS (1980a). Echinococcosis in goats of Bangladesh. Veterinary Parasitology 7: 103-107.

92. Islam AWMS (1980b). Echinococcus granulosus in dogs in Bangladesh. American Journal of Veterinary Research 41: 415-416.

93. Islam AWMS (1981). Echinococcosis in goats. Indian Veterinary Journal 58: 999-1000.

94. Islam AWMS (1982). The prevalence of hydatid disease in buffaloes in Bangladesh. Annals of Tropical Medicine and Parasitology 76: 623-626.

95. Islam KS and Awal MA (1991). Schistosome dermatitis in Bangladesh. Indian Journal of Parasitology 15: 165-169.

96. Islam MA, Haque M, Rahman A, Rahman MM, and Rahman MA and Haque F (1983). Economic losses due to brucellosis among cattle in Bangladesh. Bangladesh Veterinary Journal 17: 56-62.

97. Islam MK, Basak SC, Majumder S, Sarder SA, Islam AWMS et al. (2003). Cystic echinococcosis in domestic ruminants in Cox's Bazr of Bangladesh. Pakistan Journal of Scientific Industrial Research 46: 251-254.

98. Islam MM, Siddiqui MAR, Haque MA, Baki MA, Majumder S, Parrish JJ and Shamsuddin M (2007). Screening some major communicable diseases of AI bulls in Bangladesh. Livestock Research for Rural Development 19: 1-9.

99. Islam MN, Rahman MM, Rahman MH, Khan IA and Rahman H (1999). Diseases encountered at meat inspection in selected abattoirs and their public health significance. Bangladesh Veterinarian 16: 15-18.

100. Islam N, Rashid MU and Cuellan CB (1977). Hydatid cysts in bovines, caprines and ovines in Dacca, Bangladesh. American Tropical Medicine and Parasitology 71: 239-241. 
101. Islam MR, Huque AKMF, Khan MAHNA and Talukder MRI (2000). Balantidiosis in water buffaloes: Incidence and therapeutic trial. Bangladesh Journal of Agricultural Science 27: 143-146.

102. Islam MS and Samad MA (1998). Clinical observation and management of Foot-and-mouth disease outbreaks in cattle in Tangail Milk-shed area. Bangladesh Veterinary Journal 32: 47-52.

103. Islam MS, Alam MM, Rahman MM and Ahmed MU (2009). Rotavirus infection in human and birds. Bangladesh Journal of Veterinary Medicine 7: 314-319.

104. Kabir MHB, Eliyas M, Hashem MA, Mohiuddin and Miazi OF (2010). Prevalence of zoonotic parasitic diseases of domestic animals in different abattoir of Comilla and Brahman Baria region in Bangladesh. University Journal of Zoology Rajshahi University 28: 21-25.

105. Karim MJ, Shaikh H and Huq MM (1981). Incidence of Taenid parasites in stray dogs of Mymensingh district, Bangladesh. Bangladesh Veterinary Journal 15: 1-5.

106. Karim MJ, Shaikh H and Huq MM (1982). Prevalence of larval taenids in goats in Bangladesh. Tropical Animal Health and Production 14: 166.

107. Khan AM, Khan AQ, Dobrzynski L, Joshi GP and Myat AA (1981). A Japanese encephalitis focus in Bangladesh. Journal of Tropical Medicine and Hygiene 84: 41- 44.

108. Khan WA, Rogers KA, Karim MM, Ahmed S, Hibberd PL, Calderwood SB, Ryan ET and Ward HD (2004). Cryptosporidiosis among Bangladesh children with diarrhea: A prospective, matched, case-control study of clinical features, epidemiology and systemic antibody responses. American Journal of Tropical Medicine and Hygiene 71: 412-419.

109. Kilgore PE, Unicomb LE, Gentsch JR, Albert MJ, McElroy CA and Glass RI (1996). Neonatal rotavirus infection in Bangladesh: strain characterization and risk factors for nosocomial infection. Pediatrics Infectious Disease Journal 15: 672-677.

110. Kuddus R (2010). Containing anthrax outbreak: Some suggestions. The Daily Star, May 6, www.biosecuritycommons.org/index.php? title=Anthrax.

111. Luby SP, Hossain JM, Gurley ES, Ahmed B, Banu S, Khan SU, Homaria N, Rota PA, Rollin PE, Comer JA, Kenah E, Ksiazek TG and Rahman M (2009a). Recurrent zoonotic transmission of Nipah virus into humans, Bangladesh, 2001-2007. Emerging Infectious Diseases 15: 1-8.

112. Luby SP, Rahman M, Hossain MJ, Blum IS, Husain MM, Gurley E et al. (2006b). Foodborne transmission of Nipah virus, Bangladesh. Emerging Infectious Diseases 12: 1888-1894.

113. Luby SP, Curley ES and Hossain MJ (2009b). Transmission of human infection with Nipah virus. Clinical Infectious Diseases 49: 1743-1748.

114. Masuduzzaman M, Hossain MI, Moslehuddin M and Bhuiyan MJ (1998). Pathological conditions encountered in food animal carcasses in abattoirs of Bangladesh. Bangladesh Veterinarian 15: 19-22.

115. Mohan RW and Ali SM (1948). Some aspects of anthrax in Bengal. Indian Journal of Veterinary Science 8,1 .

116. Mondal D, Singh SP, Kumar N, Joshi A, Sunder S, Das P, Siddhivinayak H, Kroeger A and Boelaert M (2009). Visceral leishmaniasis elimination programme in India, Bangladesh and Nepal: Reshaping the case finding/ case management strategy. PLoSNeg/Tropical Diseases 3:e355.

117. Montgomery JM, Hossain MJ, Gurley E, Carroll DS, Croisier A, Bertherat E et al. (2008). Risk factors Nipah virus encephalitis in Bangladesh. Emerging Infectious Diseases 14: 1526-1532.

118. Muhammad N, Hossain MA, Musa AK, Mahmud MC, Paul SK, Rahman MA, Haque N, Islam MT, Parvin US, Khan SI, Nasreen SA and Mahmud NU (2010). Seroprevalence of human brucellosis among the population at risk in rural area. Mymensingh Medical Journal 19: 1-4.

119. Mustafa AHM (1984). Isolation of anthrax bacillus from an elephant in Bangladesh. Veterinary Record 114: 59.

120. Nahar A and Ahmed MU (2009). Sero-prevalence study of brucellosis in cattle and contact human in Mymensingh district. Bangladesh Journal of Veterinary Medicine 7: 269-274

121. Nooruddin M and Khaleque MA (1986). Prevalence of bovine dermatophilosis in Bangladesh. Indian Journal of Animal Science 56: 337-338.

122. Pervin M, Tabassum S, Ali MM, Mamun KZ and Islam MN (2004). Clinical and laboratory observations associated with the 2000 dengue outbreak in Dhaka, Bangladesh. Dengue Bulletin 28: http://www.searo.who. int/EN/Section 10/Section 332 /Section1985_980. 
123. Pharo HJ, Motalib A, Alam S, Fraser GC and Routledge SF (1981). Preliminary information on the prevalence of bovine brucellosis in the Pabna Milk-shed area of Bangladesh. Bangladesh Veterinary Journal 15: 43-51.

124. Pharo HJ, Motalib A, Routledge SF and Alam S (1981). The prevalence of bovine tuberculosis in the Bangladesh Cattle Development Project. Bangladesh Veterinary Journal 15: 53-56.

125. Podder G, Breiman RF, Azim T, Thu HM, Velathanthiri N, Mai LQ, Lowry K and Aaskov JG (2006). Origin of Dengue type-3 viruses associated with the Dengue outbreak in Dhaka, Bangladesh, in 2000 and 2001. American Journal of Tropical Medicine and Hygiene 74: 263-265.

126. Rahman KM and Islam N (1983). Resurgence of visceral leishmaniasis in Bangladesh. Bulletin World Health Organization. 61: 113-116.

127. Rahman AS, Sanyal SC, Al-Mahmud KA, Sobhan A, Hossain KS and Anderson BC (1984). Cryptosporidiosis in calves and their handlers in Bangladesh. Lancet 2(8306): 221.

128. Rahman M, Shahid NS, Rahman H, Sack DA, Rahman N and Hossian S (1990). Cryptosporidiosis: a cause of diarrhea in Bangladesh. American Journal of Tropical Medicine and Hygiene. 42: 127-130.

129. Rahman MA and Mia AS (1970). A study of brucellosis in Bangladesh. Bangladesh Journal of Animal Science 3: 39-44.

130. Rahman MA, Islam MS, Alam MGS and Shamsuddin M (1997). Seroprevalence of brucellosis in the buffalo (Bubalus bubalis) of a selected area in Bangladesh. Buffalo Journal 2 : 209-214.

131. Rahman MS, Han JC, Park J, Lee JH, ED SK and Chae JS (2006). Prevalence of brucellosis and its association with reproductive problems in cows in Bangladesh. Veterinary Record 159: 180-182.

132. Rahman M, Sultana R, Ahmed G, Nahar S, Hassam ZM, Saiada F, Podder G, Faruque ASG, Siddique AK, Sack DA, Matthijnssens J, Ranst MV and Azim T (2007). Prevalence of G2P[4] and G12P[6] rotavirus, Bangladesh. Emerging Infectious Diseases 13: 18-24.

133. Rahman MF, Ershaduzzaman M, Debnath NC, Rahman MM and Rahman MB (1992). Prevalence of Rotavirus infection in calves of Bangladesh. Bangladesh Veterinarian 9: 84-87.

134. Rahman MH (1973). Incidence of some helminth parasites of zoonotic significance in street dogs in some districts of Bangladesh. Bangladesh Veterinary Journal 7: 14-16.

135. Rahman KM, Islam S, Rahman MW, Kenah E, Zahid MM, Rahman M, Haque R and Stephen P (2009). Incidence of Kala-azar and post-kala-azar dermal leishmaniasis in a population-Bangladesh. ${ }^{\text {th }}$ Worldleish Congress on Leishmaniasis 2009. pp. 1-4 http://www.worldleish4. org/program_details.php?controlld=16

136. Rahman MM, Chowdhury TIMFR and Chowdhury MUA (1978a). Investigation of brucellosis among cattle. Bangladesh Veterinary Journal 12: 12-15.

137. Rahman MM, Chowdhury TIMFR, Rahman MM and Hossain WIMA (1978b). Occurrence of Salmonella and Escherichia in water obtained from various sources and their impact on public health. Bangladesh Veterinary Journal 12: 16-20.

138. Rahman MM and Rahman MA (1981). Incidence of Brucella infection in subclinical mastitic udder. Bangladesh Veterinary Journal 15: 39- 42.

139. Rahman MM and Rahman MS (1982). Study on the prevalence of brucellosis in cows in organized farms and domestic holdings in Bangladesh. Bangladesh Veterinary Journal 16: 53-58.

140. Rahman MM, Chowdhury TIMFR, Rahman MA and Haque F (1983). Seroprevalence of human and animal brucellosis in Bangladesh. Indian Veterinary Journal 60: 165-168.

141. Rahman MM, Haque M and Rahman MA (1988). Seroprevalence of caprine and human brucellosis in some selected areas of Bangladesh. Bangladesh Veterinary Journal 22: 85-92.

142. Rahman MM, Rahman MH, Rahman MA, Hoque AKMM and Islam N (1997). Microbial status and public health significance of goat meat sold in rural markets of Bangladesh. Progress Agriculture 8: 121-124.

143. Rahman MM and Samad MA (2008). Prevalence of bovine tuberculosis and its effects on milk production in Red Chittagong cattle. Bangladesh Journal of Veterinary Medicine 6: 175-178.

144. Rahman MM and Samad MA (2010). Prevalence of sub-clinical gastro-intestinal parasitosis and their effects on milk production with therapeutic management in Red Chittagong cattle. Bangladesh Journal of Veterinary Medicine 8: 11-16.

145. Rahman MN, Sen MM, Haque MF and Rahman A (1988). A survey on the diseases of dog at Central Veterinary Hospital Dhaka. Bangladesh Veterinary Journal 22: 59-62. 
146. Rahman M, Rahman K, Siddique AK, Shoma S, Kamal AHM, Ali KS, Nisaluk A and Breiman RF (2002). First outbreak of dengue haemorrgahic fever, Bangladesh. Emerging Infectious Diseases 8: 738-740.

147. Rashid MA, Nooruddin M and Dey AS (1996a). Distribution of dermatomycosis in cattle, goats and their in contact humans. Bangladesh Veterinarian 13: 9-12.

148. Rashid MA and Nooruddin M (1996b). Distribution of the causal fungi of dermatomycosis in cattle, goats and their in contact humans. Bangladesh Veterinarian 13: 13-16.

149. Russell PK, Buescher EL, McCown JM and Ordonez J (1966). Recovery of dengue viruses from patients during epidemics in puerto Rico and East Pakistan. American Journal of Tropical Medicine and Hygiene 15: 573-579.

150. Samad MA (2000a). Clinico-therapeutic management of severe complicated cases of contagious ecthyma in Black Bengal goats. Bangladesh Veterinary Journal 34: 39- 42.

151. Samad MA (2000b). An overview of livestock research reports published during the twentieth century in Bangladesh. Bangladesh Veterinary Journal 34: 53-149.

152. Samad MA (2008). Animal Husbandry and Veterinary Science. $1^{\text {st }}$ Pub., LEP No. 11, BAU Campus, Mymensingh, Bangladesh.

153. Samad MA, Chhabra MB and Gautam OP (1982). Note on the prevalence of Toxoplasma gondii antibodies in cattle in Bangladesh. Indian Journal of Animal Science 52: 601-603.

154. Samad MA and Haque ME (1986). Anthrax in man and cattle of Bangladesh. Journal of Tropical Medicine and Hygiene 89: 43-45.

155. Samad MA and Rahman MS (1986). Incidence of bovine tuberculosis and its effect on certain blood indices in dairy cattle of Bangladesh. Indian Journal of Dairy Science 39: 231-234.

156. Samad MA and Ahmed MU (1990). Epidemiological investigation of rotavirus infection in buffalo calves in Bangladesh. Proceeding of Domestic Buffalo Production in Asia (IEA/FAO)195-200.

157. Samad MA and Begum N (1990). Epidemiology and clinical status of toxoplasmosis in man and animals. Bangladesh Veterinarian 7: 50-74.

158. Samad MA (1992). Serological diagnosis of Toxoplasma gondii associated with abnormal reproduction in Black Bengal goats. Preventive Veterinary Medicine 13: 217-220.

159. Samad MA, Rahman KB and Halder AK (1993a). Seroprevalence of Toxoplasma gondii in domestic ruminants in Bangladesh. Veterinary Parasitology 47: 157-159.

160. Samad MA, Rahman KB and Bashar SA (1993b). Serological status to natural Toxoplasma gondii infection in mixed flocks of sheep and goats in Bangladesh. Journal of Parasitological Research 3: 25-28.

161. Samad MA, Begum N, Shamsunahar and Ahmed MU (1993c). serological diagnosis of Toxoplasma gondii infection in human associated with gynaeco-obsterical problems. Southeast Asian Journal of Tropical Medicine and Public Health 24: 102-106.

162. Samad MA and Begum N (1994). Present status of diagnosis and control of toxoplasmosis in domestic animals and humans. International Journal of Animal Science 9: 9-19.

163. Samad MA, Dey BC, Chowdhury NS, Akhtar S and Khan AKMMR (1997). Seroepidemiological studies on Toxoplsama gondii infection in man and animals in Bangladesh. Southeast Asian Journal of Tropical Medicine and Public Health 28: 339-343.

164. Samad MA and Rahman MH (1998). Investigation of endoparasites infection in stray cats in Bangladesh. Bangladesh Veterinary Journal 32: 142-151.

165. Samad MA, Dey BC, Akhtar S, Islam MR and Rahman AKMM (1998). Sero-histologic diagnosis of Toxoplasma gondii infection in women associated with fetal death in Bangladesh. Bangladesh Medical Journal 27: 34-35.

166. Samad MA, Dey BC and Khan AKMMR (1999). Seroprevalence of Rubella, Toxoplsma gondii and CMV among the pregnant mothers attending a medical college hospital in Bangladesh. Bangladesh Medical Journal 28: 36-39.

167. Sanekata T, Ahmed MU, Kader A, Taniguchi K and Kobayashi N (2003). Human group B rotavirus infections cause severe diarrhea in children and adults in Bangladesh. Journal of Clinical Microbiology 41: 2187-2190.

168. Seleem MN, Boyle SM and Sriranaganathan N (2010). Brucellosis: a re-emerging zoonoses. Veterinary Microbiology 140: 392-398. 
169. Schuster FL and Ramirez-Avila L (2008). Current world status of Balantidium coli. Clinical Microbiological Review 21: 626-638.

170. Selim SA, Aziz KMS, Sarker AJ and Rahman A (1991). Rotavirus infection in calves in Bangladesh. Veterinary Research Communication 15: 327-333.

171. Sengupta PC (1944). Kala-azar in Bengal: its incidence and trends. Indian Medical Gazette 79: 547-552.

172. Shahid NS, Rahman ASMH, Anderson BC, Mata LJ and Sanyal SC (1985). Cryptosporidiosis in Bangladesh. British Medical Journal 290 (6462): 114-115.

173. Shahid NS, Rahman ASMH and Sanyal SC (1987). Cryptosporidium as a pathogen for diarrhea in Bangladesh. Tropica Geographical Medicine 39: 265-270.

174. Shaikh H, Huq MM, Karim MJ and Khan MMM (1982). Incidence of helminth parasites of domestic cats and wild cats and jackals in Bangladesh. Indian Journal of Parasitology 6: 245-247.

175. Shaikh H, Huq MM, Karim MJ and Khan MMM (1983). Parasites of zoonotic importance in domestic ruminants. Pakistan Veterinary Journal 3: 23-25.

176. Siddiqui MA, Khan MAH, Ahmed SS, Anwar KS, Akhtaruzzaman SM and Salam MA (2012). Recent outbreak of cutaneous anthrax in Bangladesh: clinico-demographic profile and treatment outcome of cases attended at Rajshahi Medical College Hospital. BMC Research Notes 2012, 5:464, doi:10.1186/1756-05005-464. www.biomedcentral.com/content/pdf/1756-0500-5-464.pdf.

177. Solomon T (2006). Control of Japanese encephalitis within our grasp. New England Journal of Medicine 355: 869-871.

178. Solomon T, NI H, Beasley DWC, Ekkelenkamp M, Cardosa MJ and Barrett ADT (2003). Origin and evaluation of Japanese encephalitis virus in Southeast Asia. Journal of Virology 77: 3091-3098.

179. Sultana R, Rimi NA, Azad S, Islam MS, Khan MS, Gurley ES, Nahar N and Luby SP (2012). Bangladesh backyard poultry raisers' perceptions and practices related to zoonotic transmission of avian influenza. Journal of Infection Development Cries 6: 156-165.

180. Talukder SI, Huq MH, Rahman S, Haque MA, Sarker CB and Ali MS (2003). Epidemiological characteristics of sixty five cases of Kala-azar attending to a laboratory in Mymensingh. Mymensingh Medical Journal 12: 89-92.

181. Talukder KA, Aslam M, Islam Z, Azmi IJ, Dutta DK, Hossain S, Nur-E-Kamal A, Nair GB, Cravioto A, Sack DA and Endtz HP (2008). Prevalence of virulence genes and cytolethal distending toxin production in Campylobacter jejuni isolates from diarrheal patients in Bangladesh. Journal of Clinical Micriobiology 46: 1485-1488.

182. Talukder BC (2010). Comparison of serodiagnostic tests for the serosurveillance studies on canine brucellosis in Mymensingh Municipal Corporation Area. MS Thesis, Department of Medicine, BAU, Mymensingh.

183. Tarafder M and Samad MA (2010). Prevalence of clinical diseases of pet dogs and risk perception of zoonotic infection by dog owners in Bangladesh. Bangladesh Journal of Veterinary Medicine 8: 163-174.

184. Thappa DM and Karthiklyan K (2001). Anthrax: an overview within the Indian subcontinent. International Journal of Dermatology 40: 216-222.

185. Wagatsuma Y, Breiman RF, Hossain A and Rahman A (2004). Dengue fever outbreak in a recreation club, Dhaka, Bangladesh. Emerging Infectious Diseases 10: 747-750.

186. Wahed F, Kader SA, Akhtarunnessa and Mahamud MM (2011). Nipah virus: An emergent deadly paramyxovirus infection in Bangladesh. Journal of Bangladesh Society of Physiology 6: 134-139.

187. Weese JS, Peregrine AS and Armstrong J (2002). Occupational health and safety in small animal veterinary practice: Part 1- Nonparasitic zoonotic diseases. Canadian Veterinary Journal 43: 631-636.

188. WHO (2005). National tuberculosis program, Bangladesh. WHO project: BAN TVB 001, Regional Office for Southeast Asia, New Delhi: (TB-Report pdf).

189. WHO (2012a). Cummulative number of confirmed human cases of avian influenza A (H5N1) reported to WHO.http://www.who.int/influenza/human_animal_interface/avian_influenza/EN_GIP_20120326 CummulativeNumberH5N1 cases.pdf.

190. WHO (2012b). Avian influenza- situation in Bangladesh. http://www.who.int/csr/don/2012_03_07/ en/index.html. 
191. WHO (2012c). WHO: Fourth H5N1 case in Bangladesh has recovered. Afludiary.blogspot.com/2012/02/ Bangladesh-reporting-their- $4^{\text {th }}$-h5n1.html.

192. WHO (2012). New cases of human infection with avian influenza in Bangladesh and Indonesia. WHO, Regional Office for South East Asia. Section 1027.htm.

193. Youn H (2009). Review of zoonotic parasites in medical and veterinary fields in the republic of Korea. Korean Journal of Parasitology 47: 133-141.

194. Yunus EB (2000). Dengue outbreak 2000: the emerged issues. Bangladesh Medical Journal (Khulna) 33: 46-47.

195. Yunus EB, Bangali AM, Mahmood MAH, Rahman MM, Chowdhury AR and Talukdaer PK (2001). Dengue outbreak 2000 in Bangladesh: From speculation to reality and exercise. Dengue Bulletin 25: 15-20. 